\title{
Balancing Ecosystem Services and Disservices: Smallholder Farmers' Use and Management of Forest and Trees in an Agricultural Landscape in Southwestern Ethiopia
}

\author{
$\underline{T o l a}$ Gemechu Ango $^{1}$, Lowe Börjeson ${ }^{1}$, Feyera Senbeta $^{2}$ and Kristoffer Hylander $^{3}$
}

\begin{abstract}
Farmers' practices in the management of agricultural landscapes influence biodiversity with implications for livelihoods, ecosystem service provision, and biodiversity conservation. In this study, we examined how smallholding farmers in an agricultureforest mosaic landscape in southwestern Ethiopia manage trees and forests with regard to a few selected ecosystem services and disservices that they highlighted as "beneficial" or "problematic." Qualitative and quantitative data were collected from six villages, located both near and far from forest, using participatory field mapping and semistructured interviews, tree species inventory, focus group discussions, and observation. The study showed that farmers' management practices, i.e., the planting of trees on field boundaries amid their removal from inside arable fields, preservation of trees in semimanaged forest coffee, maintenance of patches of shade coffee fields in the agricultural landscape, and establishment of woodlots with exotic trees result in a restructuring of the forest-agriculture mosaic. In addition, the strategies farmers employed to mitigate crop damage by wild mammals such as baboons and bush pigs, e.g., migration and allocation of migrants on lands along forests, have contributed to a reduction in forest and tree cover in the agricultural landscape. Because farmers' management practices were overall geared toward mitigating the negative impact of disservices and to augment positive services, we conclude that it is important to operationalize ecosystem processes as both services and disservices in studies related to agricultural landscapes.
\end{abstract}

Key Words: agricultural landscape; biodiversity; ecosystem services and disservices; Ethiopia; farmer practices; forest; Gera; trees

\section{INTRODUCTION}

Forest patches and trees in agricultural landscapes are an important resource for many smallholding farmers in tropical regions. Apart from providing food, fodder, and fiber, the trees, woodlots, and forest patches also provide many other ecosystem services such as water and soil fertility regulation, amelioration of local microclimate, and shade (Dewees 1995, Harvey and Haber 1999, Harvey et al. 2005, Muleta et al. 2011, Smukler et al. 2012). Moreover, such forest patches and trees can contribute to biodiversity conservation because they connect forest fragments, serve as habitats, and ease pressure on protected forest areas (Manning et al. 2006, Bhagwat et al. 2008, Perfecto and Vandermeer 2008, Pulido-Santacruz and Renjifo 2011).

Forest and trees can also bring damage to local livelihoods, e.g., through harboring crop pests. For example, commercial farmers in Puerto Rico have incurred substantial economic loss due to monkeys' crop raids and resulting crop shift (Engeman et al. 2010), while in southwestern Ethiopia baboons and bush pig crop raids have been reported (Lemessa et al. 2013). Hence, although trees and forest patches are important for the provision of a diversity of ecosystem services, they also provide habitats and shelter for pests, which from a farmer's perspective is more aptly described as a disservice that has a negative impact on farmers' productivity and livelihoods, rather than a service.

The concept of ecosystem services over recent past decades has contributed to increased public awareness, especially among those distanced from nature, about the importance of nature and its sustainability for human well-being (Daily 1997, MA 2005). The ecosystem services framework illustrates how the loss of biodiversity undermines ecosystem processes that are crucial to human well-being (Gómez-Baggethun et al. 2010). This thinking has helped to mainstream the ecosystem services concept and increase political will and support for ecosystem conservation (Liu et al. 2008, Daily et al. 2009, Gómez-Baggethun et al. 2010, Norgaard 2010). However, this normative conceptual ambition is problematic when it comes to engaging with, for example, smallholding farmers who are already aware of and fully experience a range of both "services" and "disservices" from local ecosystems.

One way of conceptualizing ecosystem disservices, which we adopt in this paper, is as "functions of ecosystems that are perceived as negative for human well-being" (Lyytimäki and Sipilä 2009:311). The concept of ecosystem disservices has been used in studies of agricultural pests such as herbivores and seedeaters that reduce crop yields and increase production costs (Zhang et al. 2007) and in describing harmful effects of poisonous plants and boggy areas on livestock management (O'Farrell et al. 2007). The concept has also been used in studies of trees and forest management in urban areas, for example, to point out how diseases, like allergies, related to urban forests and trees, attraction of wild animals, and fear of crime, shape urban residents' perceptions, values, and management of green areas in ways that may negatively affect biodiversity conservation (Lyytimäki et al. 2008, Lyytimäki and Sipilä 2009, Escobedo et al. 2011).

The use of the concept of ecosystem disservices, however, is still relatively marginal, and its analytical usefulness can be contested. In the conventional conceptualization of ecosystem services, disservices are not distinguished from services. Instead, trade-offs between different ecosystem services are articulated, depending on what aspect of human well-being is analyzed and on what spatial and temporal scale (Rodríguez et al. 2006, Power 2010, Tuvendal 2012). If we take the example of mammal pests, they

${ }^{1}$ Department of Human Geography, Stockholm University, ${ }^{2}$ Center for Environment and Development Studies, College of Development Studies, Addis Ababa University, ${ }^{3}$ Department of Ecology, Environment and Plant Sciences, Stockholm University 
are part of the forest ecosystem and might be involved in many different ecosystem services, e.g., seed dispersal, or just be regarded as part of a healthy ecosystem with an intact biodiversity. However, even if crop-raiding wild mammals can be considered a service on a larger spatial scale or from a different well-being perspective, the notion of a trade-off between different kinds of services from local farmers' viewpoints and in studies of farmers' perceptions of ecosystem services, we argue, will provide an unnecessary abstract and cumbersome logic to operationalize, compared to a framework that includes services and disservices. Hence, while adopting the basic principle of trade-offs between ecosystem services (Rodríguez et al. 2006), and because we are interested in investigating how farmers manage trees by considering the benefits and problems that they associate with trees and forest, we find it useful to conceptualize ecosystem processes that farmers perceive as negative and as disservices.

Two general assumptions have guided the study: (1) that farmers will make active decisions about how to balance disservices and services in ways that they find advantageous to their livelihoods and agricultural production; (2) that farmers living close to forests engage in processes and management practices that target the reduction of ecosystem disservices associated with trees and forests more than farmers living at a distance from forests. To investigate how farmers balance trade-offs between ecosystem services and disservices at different distances from forests, we studied three examples of services and one disservice related to forest and trees on agricultural land, using qualitative and quantitative data generated from participatory field mapping, interviews, and a tree species inventory.

\section{METHODS}

\section{Research setting and process}

The research was conducted in Gera district, Jimma zone, in southwestern Ethiopia, located about $430 \mathrm{~km}$ southwest of Addis Ababa (Fig. 1). Topographically, the district is characterized by hills, valleys, and plains, within an altitudinal range of between 1390 and 2980 meters above sea level (masl). Of the total area of the district $\left(1443 \mathrm{~km}^{2}\right)$, midhighland (1500-2000 masl) comprises about $50 \%$ of the area, followed by highland (> 2000 masl, $46 \%$ ) and lowland $(<1500$ masl, $4 \%)$. The mean annual temperature of the area is about $19^{\circ} \mathrm{C}$ while average annual rainfall varies between 1880 and $2080 \mathrm{~mm}$ (Socioeconomic Profile of Gera District [SePGD], unpublished data). In 2012, Gera district had over 130,000 inhabitants (CSA 2012), with a crude population density of 90 persons per $\mathrm{km}^{2}$. Oromo is the dominant ethnic group living in the district, and a majority are Muslims (CSA 1996).

Slightly more than half of the district is covered by forest (SePGD, unpublished data), and the extent of forest cover has been reduced over the past few decades (Hylander et al. 2013). Most of this forest belongs to a state-owned enterprise, the Oromia Forest and Wildlife Enterprise. Private companies and farmers, however, own a significant proportion of the forest, which shelters wild coffee (Coffea arabica). The remaining area is mainly covered by arable land, pasture, and built-up areas (SePGD, unpublished data). Most parts of the district have a long history of coffee-based agricultural practices (Hassen 1990). In addition to coffee, maize and tef (Eragrostis tef) are two of the important crops cultivated. Honey and beef production as well as enset (Ensete ventricosum) and root crops such as taro (Colocasia esculenta) are also common (T. G. Ango, personal observation).

Fig. 1. Map of the study area. Villages are indicated by circles around the transects $(1 \mathrm{~km}$ in length, and traversed mostly by croplands, grazing fields, and home gardens). All the surveyed fields are located within these circles. The numbers listed on the map and the corresponding names in the legend represent the kebeles, the lowest administrative unit in Ethiopia and made up of a number of villages, to which the studied villages belong. The darker grey areas show forest and semimanaged forest coffee, and lighter grey areas show cultivated and settled areas (background map based on a Landsat scene from 2001).

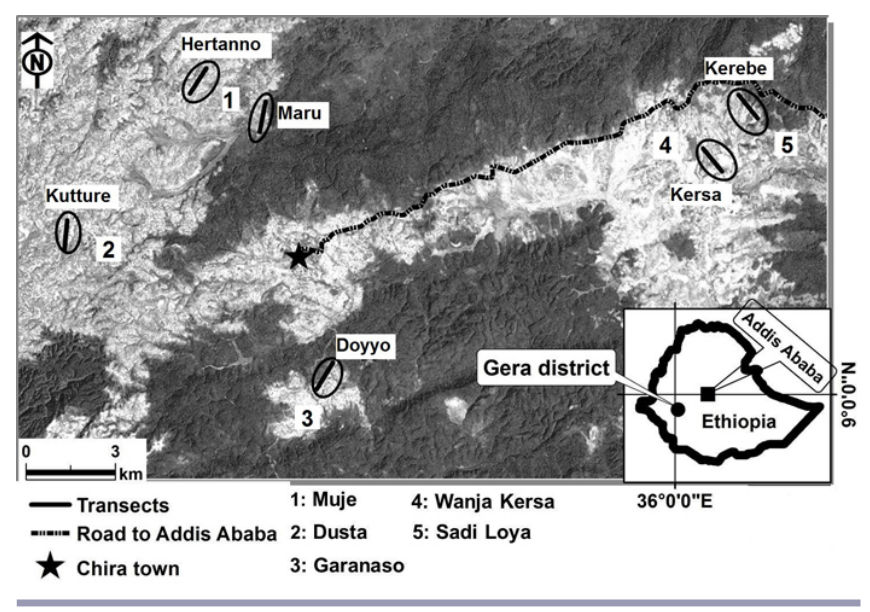

Within Gera, fieldwork was done in six strategically selected areas based on distance from forest (Fig. 1). Before going into the field, six 1-km transects, three along forest edges and three at a distance (between two and three $\mathrm{km}$ ) away from the forest edge, were identified using Google Earth. The transects were stratified based on distance to forest edge, on the assumption that forest provides important ecosystem services and might also be a source of disservices. Assuming that most wild mammal pests travel less than two km away from forest (Lemessa et al. 2013), we considered a distance of two to three $\mathrm{km}$ between transects on and away from forest edges to be adequate to capture a possible difference in management practices. The coordinates of the transects were exported to a hand-held GPS and taken to the field to identify the corresponding areas on the ground. The rural landscape in the study area is spatially divided into villages, locally recognized as gare in Afaan Oromo, consisting of a number of farmsteads or groups of farmsteads, more or less clustered, and their associated arable and forest patches. A kebele, which is the lowest administrative unit in Ethiopia, is made up of many such villages. The transects on forest edges correspond to Kerebe, Doyyo, and Maru villages, while those at a distance from the forest edges correspond to Hertanno, Kersa, and Kutture villages. Moreover, three of the villages, Kerebe, Kersa, and Doyyo, are located in the coffee-growing altitudinal zone (1500-2100 masl) whereas the other three villages lie at higher elevations (2100-2400 masl).

To illustrate how farmers balance trade-offs between ecosystem services and disservices related to forest and trees on agricultural land, we investigated four activities or processes that moderate 
the dynamics of trees and forests in the village landscapes we have described. Shaded coffee production, honey production, and establishment of live fences were studied as examples of ecosystem services, and wild mammal crop pests and their management as an example of an ecosystem disservice. Because our investigation is not an overall assessment of services and disservices identified by farmers, other services (and disservices), were not investigated in any detail in this study. The example of firewood, however, is touched upon, even if this is not part of the analytical focus. A common feature of the services we studied is that farmers highlighted them, not primarily as provisioning services, but for their role in supporting and augmenting coffee, honey, and crop production in different ways. The disservice we selected, i.e., wild mammal crop pests, was an agricultural problem that farmers often mentioned.

\section{Data collection}

Data for the study were gathered at three different periods: exploratory fieldwork from 7 to 17 September 2010 and two fieldwork periods from 3 May to 10 July 2011 and from 19 February to 23 March 2012. Participatory field mapping, semistructured interviews, focus group discussions, and observation were used to generate both quantitative and qualitative data (Elwood 2010).

Most data were acquired in 2012 through participatory field mapping and semistructured interviews with 54 farmers living in the selected villages ( 9 from each village). The farmers were selected through stratified (based on wealth status) random sampling. For this paper, however, the data from different wealth groups were pooled to focus on the geographical location of farms as a key variable. Of the 54 households covered by participatory field mapping and semistructured interviews nearly all (93\%) were headed by males. This pattern was similar across the six villages. All fields used by the selected households, both nearby and at a distance from the farmsteads, were identified, together with residents of the farmstead, through field walking and high resolution satellite images (World View 2, from 27 October to 2 November 2011).

Broadly, the different types of fields (land uses) used by the interviewed farmers can be grouped as annual crop fields (mainly cereals), grazing land, home gardens, coffee (mainly semimanaged forest coffee), forest, and woodlot. A home garden refers to a homestead and the various crops grown within it, though its composition varies considerably in size and crop diversity among farms. Based on the land cover type during the 2011 cropping season, the interviewed farmers had 349 fields, all of which were included in the study (Table 1). A majority (264) of these fields, which were located along the transects, were physically visited and mapped (identified and outlined on a high-resolution satellite image). Data on the remaining 85 (24\%) fields, including all semimanaged forest coffee and natural forest and some crop and grazing lands located in different villages from that of their owners, were based only on interviews (Tables 1,2).

During field mapping, we recorded all tree and shrub species in all visited (mapped) fields and their respective locations, except in semimanaged forest coffee and natural forest. According to our conversion of field sizes from farmers' statements in the local unit to hectares (ha), which we also corroborated with the mapped field areas, the average size of fields was 0.32 ha (Table 2). The mapping was followed by semistructured interviews for each field. We interviewed all the selected farmers, with a focus on land use, management and use of trees and forest, and their perception and management of associated ecosystem services and disservices. We also conducted focus group discussions, some conducted during the fieldwork in 2011 and others in 2012, with groups of five to nine farmers in each village to understand the general patterns of trees on agricultural land, wild mammal crop-raiders, and related management practices. Most of these issues were posed to participants as open questions for discussion. "Maize seeds" were provided to participants to rank the mammal crop-raiders that they listed, based on their perceptions of the levels of damage each pest caused to crops. The extensive walking across the landscape between fields for participatory field mapping and semistructured interview also offered ample opportunity for observation and spontaneous discussion with local residents, which provided important additional insights that were explored further in focus groups and interviews.

Preliminary results were reported back to informants in the form of a pamphlet containing photographs and a brief popularized summary of preliminary findings. The pamphlet was prepared in the local language, Afaan Oromo, and distributed in March 2012. The feedback and responses from informants on the pamphlet were highly positive and supportive, but important critical comments were also received. Discussing the pamphlet provided an opportunity for us to check that our main findings and categorizations were regarded as relevant and sound by the informants (Årlin et al., in press), which assisted us in the analysis of the qualitative material as well as in structuring the statistical tests.

\section{Data analysis}

Qualitative data from group discussions, individual interviews, and conversations with farmers in addition to our own observations were thematically analyzed as management of either ecosystem services or disservices. The analysis focused on the four selected practices: shaded coffee production, honey production, establishment of live fences, and wild mammal crop pest mitigation.

We analyzed quantitative information on the use and management practices of the same ecosystem services and disservices by comparing answers from farmers close to and far away from forest through a Chi-square test. In this analysis, we pooled all the interviews from close to forest and far from forest, respectively.

We also tested whether there were any differences in number of tree species managed in the agricultural lands for the following comparisons: (a) inside fields or along the boundary of fields, (b) villages close to forest or far from forest, and (c) variation among the different villages. The mean number of tree species per farmer, calculated separately for each field type and log-transformed, was used as our dependent variable using linear modeling and mixedeffect linear modeling in the free software $\mathrm{R}$ version 2.11.1 ( $\mathrm{R}$ Development Core Team 2010). Four models were then applied: (1) number of tree species versus field location (inside vs. boundary) and location in respect to the forest (close to or far) in a mixed-effect model with village as random factor; (2) number of tree species and location to the forest (close vs. far) and whether it was planted or retained with village as random factor; (3) 
Table 1. Percentages of different field types and percentages of fields that contain trees. Percentages relate to number of fields owned by the interviewed farmers. $\uparrow$ Includes both cultivated and semimanaged forest coffee. $\$$ Includes different land uses such as graveyard, mixed land uses, e.g., cereals and coffee, khat (Catha edulis), and sugarcane. f: Villages located far from forest edge. n: Villages located along forest edge. N: Total number of fields in a village or in a land use category, which the percentages represent.

\begin{tabular}{|c|c|c|c|c|c|c|c|c|c|c|c|c|c|c|}
\hline \multirow[t]{2}{*}{ Village } & \multicolumn{8}{|c|}{$\%$ of different field types the interviewed farmers owned } & \multicolumn{6}{|c|}{$\%$ of fields that contain trees } \\
\hline & $\begin{array}{c}\text { Annual } \\
\text { crop }\end{array}$ & $\begin{array}{c}\text { Grazing } \\
\text { land }\end{array}$ & $\begin{array}{l}\text { Home } \\
\text { garden }\end{array}$ & $\begin{array}{c}\text { Coffee } \\
(\dagger)\end{array}$ & $\begin{array}{l}\text { Other } \\
(\ddagger)\end{array}$ & Forest & Woodlot & Total & $\begin{array}{l}\text { Ann- } \\
\text { ual } \\
\text { crop }\end{array}$ & $\begin{array}{c}\text { Grazing } \\
\text { land }\end{array}$ & $\begin{array}{l}\text { Home } \\
\text { garden }\end{array}$ & $\begin{array}{c}\text { Coffee } \\
(\dagger)\end{array}$ & $\begin{array}{l}\text { Other } \\
(\$)\end{array}$ & Total \\
\hline $\begin{array}{l}\text { Doyyo } \\
\text { (N) }\end{array}$ & 32.7 & 21.8 & 16.4 & 25.5 & 3.6 & 0.0 & 0.0 & $\begin{array}{c}100 \\
(\mathrm{~N}=55)\end{array}$ & 94.4 & 100 & 100 & 100 & 100 & 98.2 \\
\hline $\begin{array}{l}\text { Hertanno } \\
\text { (f) }\end{array}$ & 57.7 & 15.4 & 17.3 & 0.0 & 1.9 & 0.0 & 7.7 & $\begin{array}{c}100 \\
(\mathrm{~N}=52)\end{array}$ & 80.0 & 100 & 100 & 0 & 0 & 85.4 \\
\hline $\begin{array}{l}\text { Kerebe } \\
\text { (N) }\end{array}$ & 38.3 & 23.3 & 16.7 & 18.3 & 1.7 & 1.7 & 0.0 & $\begin{array}{c}100 \\
(\mathrm{~N}=60)\end{array}$ & 43.5 & 85.7 & 100 & 100 & 100 & 74.6 \\
\hline Kersa (f) & 39.3 & 26.2 & 14.8 & 11.5 & 6.6 & 0.0 & 1.6 & $\begin{array}{c}100 \\
(\mathrm{~N}=61)\end{array}$ & 70.8 & 87.5 & 100 & 100 & 100 & 85.0 \\
\hline Kutture (f) & 43.8 & 17.2 & 14.1 & 15.6 & 3.1 & 4.7 & 1.6 & $\begin{array}{c}100 \\
(N=64)\end{array}$ & 100 & 100 & 100 & 100 & 100 & 100 \\
\hline $\begin{array}{l}\text { Maru } \\
\text { (N) }\end{array}$ & 52.6 & 19.3 & 17.5 & 3.5 & 1.8 & 5.3 & 0.0 & $\begin{array}{c}100 \\
(\mathrm{~N}=57)\end{array}$ & 96.7 & 100 & 100 & 100 & 100 & 98.1 \\
\hline $\begin{array}{l}\text { Villages } \\
\text { located } \\
\text { along forest } \\
\text { edge }\end{array}$ & 41.3 & 21.5 & 16.9 & 15.7 & 2.3 & 2.3 & 0.0 & $\begin{array}{c}100 \\
(\mathrm{~N}=172)\end{array}$ & 78.9 & 94.6 & 100 & 100 & 100 & 89.9 \\
\hline $\begin{array}{l}\text { Villages } \\
\text { located far } \\
\text { from forest } \\
\text { edge }\end{array}$ & 46.3 & 19.8 & 15.3 & 9.6 & 4.0 & 1.7 & 3.4 & $\begin{array}{c}100 \\
(\mathrm{~N}=177)\end{array}$ & 84.1 & 94.3 & 100 & 100 & 85.7 & 90.5 \\
\hline Total & $\begin{array}{c}43.8 \\
(\mathrm{~N}=153)\end{array}$ & $\begin{array}{c}20.6 \\
(\mathrm{~N}=72)\end{array}$ & $\begin{array}{c}16.1 \\
(\mathrm{~N}=56)\end{array}$ & $\begin{array}{c}12.6 \\
(\mathrm{~N}=44)\end{array}$ & $\begin{array}{c}3.2 \\
(\mathrm{~N}=11)\end{array}$ & $\begin{array}{c}2.0 \\
(\mathrm{~N}=7)\end{array}$ & $\begin{array}{c}1.7 \\
(\mathrm{~N}=6)\end{array}$ & $\begin{array}{c}100 \\
(\mathrm{~N}=349)\end{array}$ & 81.7 & 94.4 & 100 & 100 & 90.7 & 90.2 \\
\hline
\end{tabular}

number of tree species versus field location (inside or boundary) and village as a fixed factor in a linear model; and (4) how the number of tree species was affected by field location (inside and boundary) together with management (planted and retained) with village as a random variable.

For each of these four comparisons, we tested the variation for all trees, only planted trees, and only retained trees, respectively. All of these tests were performed separately for the three most common field types: annual crop fields, grazing land, and homesteads (Table 1). In all models, the interaction effect was also evaluated. We used the package $1 \mathrm{me} 4$ for the mixed-effect modeling. Only surveyed fields that were fields near the farmstead or close to and along the transects were included in the analyses (Table 2).

To analyze whether the species composition of trees differed according to their locations (inside fields and along field boundaries), we conducted a blocked multiresponse permutation test (MRPP) using the program PC-ORD (McCune and Mefford 2006). As input, we used the pooled number of fields in which the specific species were recorded, for each village, separating records inside and along the boundaries of the studied fields. Village was used as the blocking variable. We also made an indicator species analysis (Dufrêne and Legendre 1997) for the locations of trees in the studied fields using default settings in PC-ORD. The analysis generated an indicator value ranging from 0 to 100 for both locations: inside the field and on the field boundaries, respectively. The indicator values were tested for statistical significance using Monte Carlo technique with 1000 permutations.

\section{RESULTS}

\section{Management of forests and trees on agricultural land}

Fields under annual crops were the most frequent $(44 \%)$ compared with all other field types, followed by grazing land $(21 \%)$, home gardens $(16 \%)$, and coffee fields $(13 \%)$. A few farmers living in villages located at a distance from the forest, Kutture, Kersa, and Hertanno, also had their own woodlots (Table 1). The number and sizes of the different fields were quite similar for all the villages (Table 2).

Location of tree species in the agricultural landscape

Trees on agricultural land were categorized by farmers as either retained from previous natural forest or as their coppices, and regrowth or planted. By "regrowth," we refer to trees naturally growing from the soil seed bank or dispersed seeds of trees from previous forest as opposed to coppices from stumps. In all six villages, at least one tree species, in most cases, more than one tree in a field, was found in $90 \%$ of the agricultural fields and home gardens (Table 1).

For annual crop fields, more tree species were generally found along the boundaries compared with inside the fields (Fig. 2c,d). There was an overrepresentation of planted tree species along field boundaries and retained tree species inside these fields $(\mathrm{p}<$ 0.001 for the interaction between retained/planted and inside/ boundary variables in a mixed-effect model with village as random factor) (Fig. 2a,b,d). This pattern was generally similar in most villages close to and far from forest. However, there were fewer retained tree species along field boundaries in villages far away from the forest edge ( $p=0.030$ for the interaction effect between 
Table 2. Average size and number of the surveyed fields. $\dagger$ The fields size were obtained in local unit, sanga ( 8 sanga $=1$ ha) through interview. f: Villages located far from forest edge. n: Villages located along forest edge. $\$$ Includes 12 cultivated coffee fields, 8 other land uses such as graveyard and mixed land uses, e.g., cereals and coffee, khat (Catha edulis), and sugarcane fields, and 5 woodlots mapped fields.

\begin{tabular}{|c|c|c|c|c|c|c|c|c|c|c|c|c|c|c|c|}
\hline \multirow[t]{3}{*}{ Village } & \multicolumn{15}{|c|}{ Average area (in ha) $\dagger$, number of mapped fields, and standard error of mean (SE) } \\
\hline & \multicolumn{3}{|c|}{ Annual crop } & \multicolumn{3}{|c|}{ Grazingland } & \multicolumn{3}{|c|}{ Home garden } & \multicolumn{3}{|c|}{ Other mapped fields $\$$} & \multicolumn{3}{|c|}{ Total } \\
\hline & Area & No & SE & Area & No & SE & Area & No & SE & Area & No & SE & Area & No & SE \\
\hline Doyyo (n) & 0.37 & 15 & 0.06 & 0.24 & 11 & 0.04 & 0.28 & 9 & 0.06 & 0.34 & 6 & 0.14 & 0.31 & 41 & 0.04 \\
\hline Hertanno (f) & 0.36 & 26 & 0.09 & 0.50 & 6 & 0.16 & 0.22 & 9 & 0.04 & 0.02 & 4 & 0.01 & 0.32 & 45 & 0.06 \\
\hline Kerebe (n) & 0.31 & 16 & 0.03 & 0.30 & 11 & 0.06 & 0.38 & 10 & 0.11 & 0.14 & 6 & 0.04 & 0.30 & 43 & 0.03 \\
\hline Kersa (f) & 0.22 & 17 & 0.03 & 0.38 & 12 & 0.10 & 0.26 & 9 & 0.05 & 0.23 & 5 & 0.07 & 0.27 & 43 & 0.03 \\
\hline Kutture (f) & 0.35 & 18 & 0.06 & 0.42 & 11 & 0.11 & 0.26 & 9 & 0.06 & 0.17 & 3 & 0.04 & 0.34 & 41 & 0.04 \\
\hline Maru (n) & 0.40 & 29 & 0.06 & 0.42 & 11 & 0.09 & 0.27 & 10 & 0.06 & 0.13 & 1 & - & 0.37 & 51 & 0.04 \\
\hline $\begin{array}{l}\text { Villages located near } \\
\text { to forest edge }\end{array}$ & 0.37 & 60 & 0.03 & 0.32 & 33 & 0.04 & 0.31 & 29 & 0.05 & 0.23 & 13 & 0.07 & 0.33 & 135 & 0.02 \\
\hline $\begin{array}{l}\text { Villages located far } \\
\text { from forest edge }\end{array}$ & 0.32 & 61 & 0.04 & 0.42 & 29 & 0.07 & 0.25 & 27 & 0.03 & 0.14 & 12 & 0.04 & 0.31 & 129 & 0.03 \\
\hline Total & 0.33 & 121 & 0.03 & 0.38 & 62 & 0.04 & 0.28 & 56 & 0.03 & 0.19 & 25 & 0.04 & 0.32 & 264 & 0.02 \\
\hline
\end{tabular}

Fig. 2. Average numbers of tree species, recorded inside and along boundaries of annual crop fields that were: (a) planted, (b) retained, (c) planted and retained pooled for individual villages, and (d) pooled data from all villages. The statistical interpretations of the patterns are found in the text. Error bars are standard error. The sample size is found in Table 2.
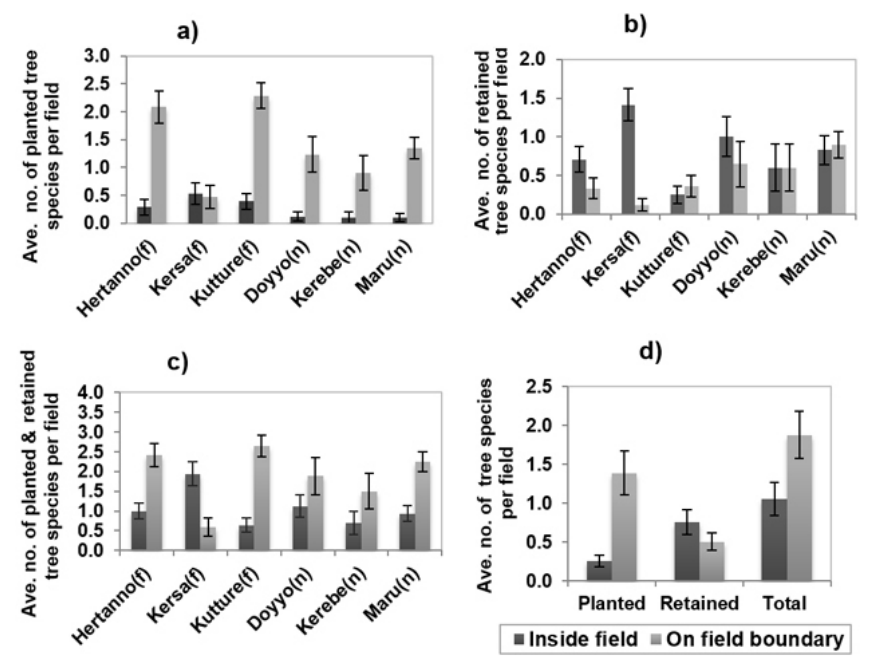

close/far and inside/boundary variables in the mixed-effect model with village as random factor; Fig. 2b).

There was a strong statistically significant pattern of more retained tree species inside grazing lands than along field boundaries, both in villages close to and away from forest $(\mathrm{p}<$ 0.001 in a mixed-effect model with village as random factor; Fig. $3 \mathrm{~b}, \mathrm{~d})$. For planted tree species, the result was less clear with more tree species along field boundaries than inside fields in villages
Fig. 3. Average numbers of tree species, recorded inside and along boundaries of grazing lands for: (a) planted, (b) retained, (c) planted and retained pooled for individual villages, and (d) pooled data from all villages. The statistical interpretations of the patterns are found in the text. Error bars are standard error. The sample size is found in Table 2.
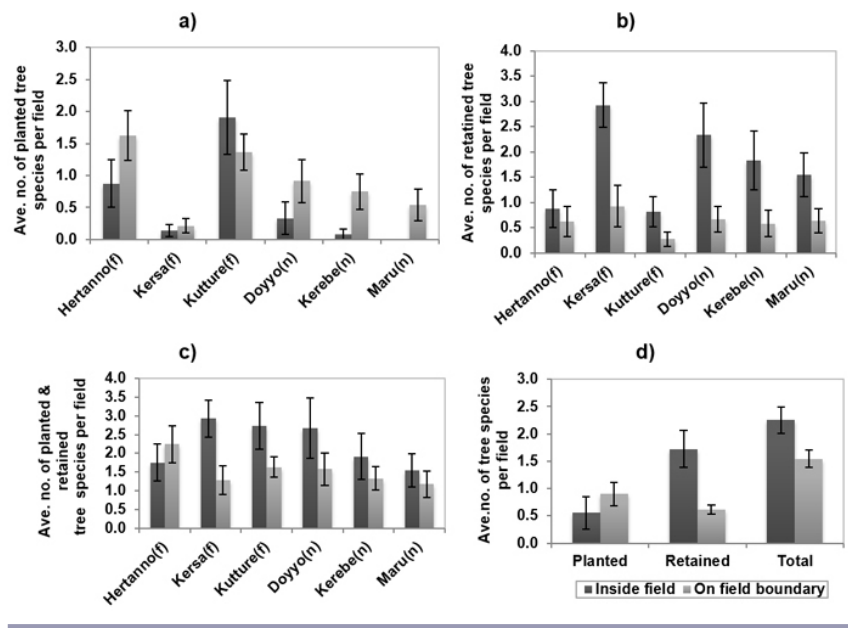

along forest edges, but an inconsistent pattern for villages away from forest (Fig. 3a; $p<0.06$ for the interaction in the mixedeffect model). On average, there were more tree species inside than along boundaries (Fig. 3d; p $<0.007$, but also a significant interaction; $\mathrm{p}<0.001$, with the management type [planted or retained as reported above]). There was a large variation among the villages in the mean number of tree species in grazing lands (Fig. 3a,b,c; p < 0.001).

For home gardens, there were in general more tree species along the boundaries compared with inside (Fig. 4c,d). Planted tree 
species were overrepresented along the boundaries of home gardens $(\mathrm{p}<0.001$ in the mixed-effect model with village as random factor), while the number of retained trees species, which were generally few, did not differ significantly in relation to location ( $p=0.14$ in the mixed-effect model with village as random factor; Fig. 4a,b,d). The patterns were generally similar in villages close to and far from forest edges, but some villages also showed inconsistencies. For example, Doyyo, Kersa, and Kerebe had more retained tree species inside home gardens compared with along boundaries unlike the pattern in the remaining three villages $(\mathrm{p}=$ 0.008 for the interaction between village and location in linear model with village as fixed factor; Fig. 4b).

Fig. 4. Average numbers of tree species, recorded inside and along boundaries of home gardens for: (a) planted, (b) retained, (c) planted and retained pooled for individual villages, and (d) pooled data from all villages. The statistical interpretations of the patterns are found in the text. Error bars are standard error. The sample size is found in Table 2.
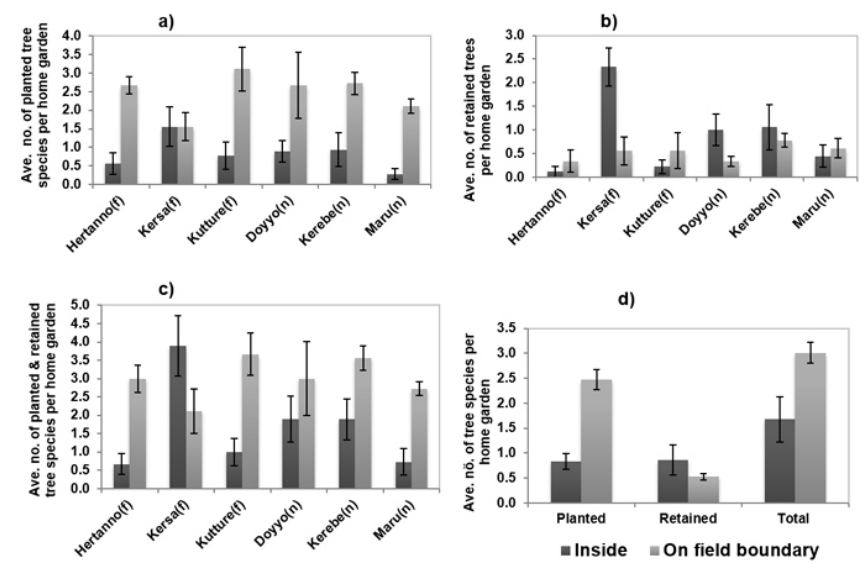

Tree species diversity in the agricultural landscape

A total of 49 tree species were recorded in the studied agricultural fields (Table A1.1). The most frequent tree species maintained, by retention or by planting were Erythrina sp. (87\% of farmers), Euphorbia ampliphylla (85\%), and Eucalyptus sp. (67\%). Only 13 tree species were kept by at least $20 \%$ of the farmers, of which two were exotic trees: Eucalyptus sp. and Cupressus lusitanica (Fig. 5).

There was a statistically significant difference between the species composition of trees managed along boundaries and inside of fields (MRPP, $p=0.012, A=0.39$ ). Several species were strongly associated with boundaries (e.g., Euphorbia ampliphylla, p = 0.003; Erythrina sp., p = 0.002; Table 3) while others had high indicator values for inside field locations (e.g., Sesbania sesban, $\mathrm{p}$ $=0.06$; Millettia ferruginea, $\mathrm{p}=0.036$; Table 3 ). Many of the other tree species were either managed both inside and along field boundaries or were managed only in a few fields (Table 3, Table A1.1, Table A2.1). Moreover, most tree species with clear tendencies of being typically found on boundaries or inside fields were planted trees (Table 3, Table A1.1).
Fig. 5. The most frequent tree species retained or planted by the interviewed farmers in the surveyed fields, based on pooled data.

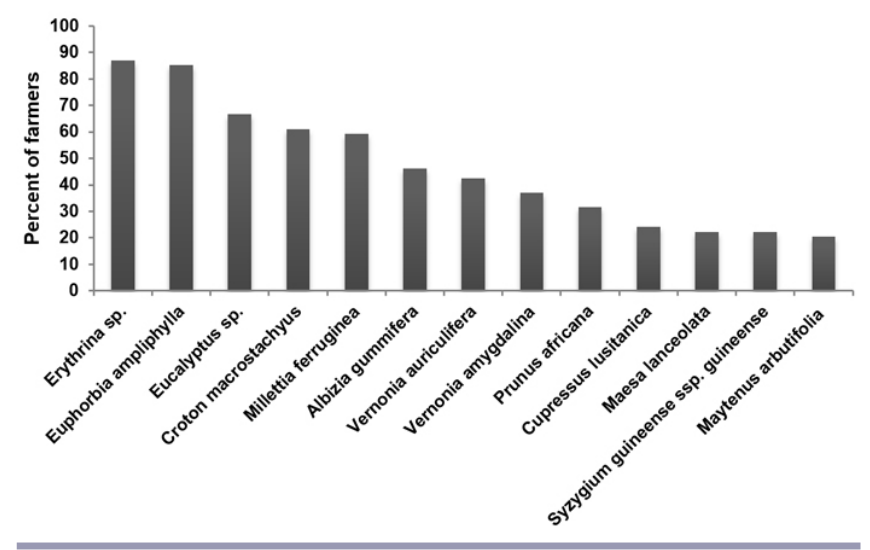

Three examples of ecosystem services from forest and trees on agricultural land

Shade trees for coffee production

Shade trees were valued for livestock, coffee, and for people to rest under and convene meetings, although farmers considered the shade for coffee as the most important benefit (Fig. 6A). About half (54\%) of the interviewed farmers owned coffee fields, mainly semimanaged forest coffee). The percentages of farmers who owned coffee fields in villages close to and away from forest edges were quite similar, even if the ones far away also had most of their fields located in the forest (Table 4). As we observed during fieldwork, most farmers also grew some coffee in their home gardens. In villages close to forests, within coffee growing altitudes, only a few young and relatively poor families or femaleheaded households did not have coffee fields.

In focus group discussions and interviews, farmers pointed out that the trees most preferred as shade for coffee were Albizia gummifera, Acacia abyssinica, and Millettia ferruginea. The reasons they mentioned were that the leaves of these trees were thin, small, and elongated, and the trees were chosen because they allow an appropriate amount of light to reach the coffee trees. It was also mentioned that the foliage of their leaves did not damage coffee trees and berries, and that they were friendly to soils, or at least without negative impact on them. In most semimanaged forest coffee systems, however, it is common to find other trees species as well. According to some of the interviewed farmers, cutting and removing mature and unsuitable trees in coffee fields is a laborious task and therefore not commonly practiced, even if the undergrowth is cleared regularly.

In villages located in the coffee growing altitudes and away from forest edges, e.g., Kersa, farmers demonstrated how they first planted or retained the preferred shade trees on land they intended to convert to coffee fields, starting a couple of years prior to planting coffee. This is done to "cool the land," i.e., to improve the microclimate prior to planting coffee. The other strategy 
Table 3. Indicator species values for tree species with an indicator value difference of more than 25 between inside and field boundaries. The table is sorted according to the difference, implying that species that are more often found inside fields have a positive value and species found at the boundaries have a negative value. P: Planted trees. R: Retained trees (from previous natural forest, coppice, or regrowth). PR: Planted or retained.

\begin{tabular}{|c|c|c|c|c|c|c|}
\hline \multirow[t]{2}{*}{ Scientific name } & \multicolumn{2}{|c|}{$\begin{array}{c}\text { No. of fields containing the } \\
\text { species }\end{array}$} & \multicolumn{2}{|c|}{ Indicator value (IV) } & \multirow[t]{2}{*}{ p-value } & \multirow[t]{2}{*}{$\begin{array}{l}\text { Difference } \\
(a-b)\end{array}$} \\
\hline & Inside & On boundary & Inside (a) & Boundary (b) & & \\
\hline Sesbania sesban $(\mathrm{P})$ & 7 & 0 & 67 & 0 & 0.060 & 67 \\
\hline Ficus sur $(\mathrm{R})$ & 11 & 1 & 61 & 1 & 0.099 & 60 \\
\hline Ricinus communis $(\mathrm{P})$ & 7 & 2 & 65 & 7 & 0.170 & 58 \\
\hline Millettia ferruginea (PR) & 57 & 23 & 71 & 29 & 0.036 & 42 \\
\hline Bersama abyssinica $(\mathrm{R})$ & 17 & 5 & 52 & 11 & 0.306 & 41 \\
\hline Schefflera abyssinica $(\mathrm{R})$ & 5 & 1 & 42 & 3 & 0.420 & 39 \\
\hline Acacia lahai $(\mathrm{R})$ & 9 & 2 & 41 & 3 & 0.426 & 38 \\
\hline Maytenus arbutifolia $(\mathrm{R})$ & 15 & 8 & 54 & 17 & 0.358 & 37 \\
\hline Brucea antidysenterica $(\mathrm{R})$ & 2 & 0 & 33 & 0 & 0.455 & 33 \\
\hline Cassipourea malosana $(\mathrm{R})$ & 2 & 0 & 33 & 0 & 0.464 & 33 \\
\hline Albizia gummifera (PR) & 39 & 20 & 55 & 23 & 0.398 & 32 \\
\hline Vernonia amygdalina (PR) & 21 & 10 & 56 & 27 & 0.434 & 29 \\
\hline Acacia abyssinica $(\mathrm{R})$ & 19 & 2 & 30 & 3 & 0.577 & 27 \\
\hline Apodytes dimidiata $(\mathrm{R})$ & 7 & 1 & 29 & 2 & 0.455 & 27 \\
\hline Pterolobium stellatum $(\mathrm{P})$ & 0 & 2 & 0 & 33 & 0.447 & -33 \\
\hline Euphorbia cotinifolia $(\mathrm{P})$ & 1 & 4 & 3 & 40 & 0.425 & -37 \\
\hline Vernonia auriculifera $(\mathrm{R})$ & 14 & 33 & 25 & 70 & 0.133 & -45 \\
\hline Justicia schimperiana (PR) & 0 & 7 & 0 & 50 & 0.183 & -50 \\
\hline Erythrina sp. (P) & 6 & 132 & 2 & 96 & 0.002 & -94 \\
\hline Euphorbia ampliphylla $(\mathrm{P})$ & 5 & 133 & 2 & 96 & 0.003 & -94 \\
\hline
\end{tabular}

farmers use when they convert treeless fields to coffee is the planting of coffee together with fast-growing and shorter living trees, e.g., Sesbania sesban and Ricinus communis, and some of the preferred shade trees mentioned above. The fast-growing and shorter lived trees provide enough shade to the newly planted coffee until the preferred shade trees have grown big enough.

Fig. 6. Semimanaged forest coffee (A), beehives hung on a tree (B), and live fence made from Euphorbia ampliphylla (C). Also note the beehives on a shade tree in A.

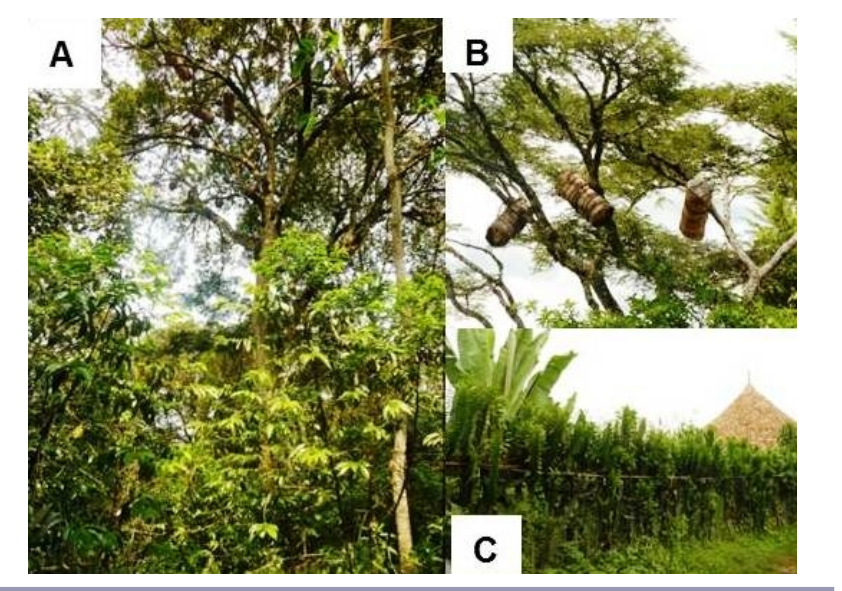

Honey production

After coffee, honey is considered as the second most important source of cash income by many farmers in the area. Most of the interviewed famers $(72 \%)$ were engaged in honey production, though the numbers of hives they possessed varied from a few to over 50 (Table 4$)$. There was a tendency for more farmers $(85 \%)$ living in villages close to forest edges to engage in honey production as compared with those living away from forest $(59 \%$; $\mathrm{p}=0.068)$.

Honey production is mainly conducted using traditional techniques and tools (Figs. 6A,B). According to farmers, beehives (baskets) are produced locally from trees such as Millettia ferruginea, Ficus sur, Polyscias fulva, Euphorbia ampliphylla, Erythrina sp., Croton macrostachyus and Arundinaria alpina. The beehives are mostly hung up on small branches in trees in forest and semimanaged forest coffee fields, and to some extent on trees in agricultural land.

Farmers also reported that honeybees forage on any flowers though they associate honey harvests with the flowering of certain tree species: Vernonia amygdalina, Schefflera abyssinica, and Croton macrostachyus, and herbs, mainly Bidens spp., which flowers at different times of the year and thus offers a possibility of harvesting honey up to four times per annum in some cases.

\section{Live fences}

Live fences, which are lines of densely planted trees mostly interconnected with dead wood, are another important function of trees in the area (Fig. 6C). According to farmers, trees such as 
Table 4. Issues related to farmers' use of some ecosystem services from and related to trees and forest (in 2011). f: Villages located far from forest edge. $n$ : villages located along forest edge. N: Sample size of farmers per village or number of fields per land-use type from which the percentages were calculated.

\begin{tabular}{|c|c|c|c|c|c|}
\hline \multirow[t]{3}{*}{ Village } & \multicolumn{5}{|c|}{ Ecosystem services (shade, honey, and fencing) } \\
\hline & \multicolumn{2}{|c|}{$\begin{array}{c}\% \text { of farmers }(\mathrm{N}=9 \text { per village }) \\
\text { engaged in }\end{array}$} & \multicolumn{3}{|c|}{$\%$ of fields with live fence } \\
\hline & $\begin{array}{c}\text { Coffee } \\
\text { production }\end{array}$ & Honey production & Home garden & Annual crop fields & Total (all) fields \\
\hline Doyyo (n) & 77.8 & 100 & $100(\mathrm{~N}=9)$ & $61.1(\mathrm{~N}=18)$ & $60.0(\mathrm{~N}=55)$ \\
\hline Hertanno (f) & 0 & 55.6 & $100(\mathrm{~N}=9)$ & $56.7(\mathrm{~N}=30)$ & $63.5(\mathrm{~N}=52)$ \\
\hline Kerebe (n) & 77.8 & 55.6 & $80.0(\mathrm{~N}=10)$ & $30.4(\mathrm{~N}=23)$ & $45.0(\mathrm{~N}=60)$ \\
\hline Kersa (f) & 55.6 & 55.6 & $55.6(\mathrm{~N}=9)$ & $29.2(\mathrm{~N}=24)$ & $23.0(\mathrm{~N}=61)$ \\
\hline Kutture (f) & 88.9 & 66.7 & $100(\mathrm{~N}=9)$ & $92.9(\mathrm{~N}=28)$ & $78.1(\mathrm{~N}=64)$ \\
\hline Maru (n) & 22.2 & 100 & $100(\mathrm{~N}=10)$ & $73.3(\mathrm{~N}=30)$ & $63.2(\mathrm{~N}=57)$ \\
\hline Villages along forest edge & 59.3 & 85.2 & $93.1(\mathrm{~N}=29)$ & $56.3(\mathrm{~N}=71)$ & $55.8(\mathrm{~N}=172)$ \\
\hline $\begin{array}{l}\text { Villages located far from } \\
\text { forest edge }\end{array}$ & 48.1 & 59.3 & $85.2(\mathrm{~N}=27)$ & $61.0(\mathrm{~N}=82)$ & $54.8(\mathrm{~N}=177)$ \\
\hline Total (all) fields & 53.7 & 72.2 & $89.3(\mathrm{~N}=56)$ & $58.8(\mathrm{~N}=153)$ & $55.3(\mathrm{~N}=346)$ \\
\hline $\begin{array}{l}\text { Chi-square for villages along } \\
\text { forest vs. far from forest edge }\end{array}$ & 0.298 & 3.323 & 0.276 & 0.174 & 0.007 \\
\hline $\begin{array}{l}\text { P-value for villages along } \\
\text { forest vs. far from forest edge }\end{array}$ & 0.585 & 0.068 & 0.600 & 0.677 & 0.934 \\
\hline
\end{tabular}

Erythrina sp., Euphorbia ampliphylla, Vernonia auriculifera, Justicia schimperiana, Pterolobium stellatum, Dracaena sp., and Euphorbia cotinifolia are widely used for live fencing because most of these trees grow fast. Farmers also reported that they preferred these trees for live fencing because trees such as Erythrina sp. and Euphorbia ampliphylla and Justicia schimperiana can be propagated by cutting, and that the first two have thorns that make them suitable for fences.

Of all the studied fields, most home gardens (89\%), and a majority of the annual crops fields $(59 \%)$ had live fences (Table 4$)$. The proportions of fields that had live fences were quite similar among the villages, with a couple of exceptions (Table 4). Farmers claimed that the major reason for the prevalence of live fences was the need to protect crops, mainly from domestic animals. Some 20 years ago and earlier, farmers, for example in Hertanno but also more generally in the district, used to tend livestock in communal grazing fields. However, because most of these grazing lands have now been converted to cropland, farmers have started to tether livestock individually on whatever land they own, including grazing land. At the same time, live fences have also expanded because they help to shield livestock from crops. Notably, farmers also consistently reported that live fences were ineffective as protection against many wild mammal crop pests such as baboons, monkeys, and giant forest hogs, but many also agreed that strong (matured), tight, and maintained live fences could keep bush pigs and porcupines away from crops.

Wild mammal crop pests: as an example of ecosystem disservices from and related to forests and trees in agricultural lands

Wild mammal crop pests such as bush pigs, baboons, giant forest hogs, warthogs, common monkey, and porcupine were an often mentioned agricultural problem by farmers, especially in villages close to forests. Most of the studied fields (63\%) were, for instance, visited by at least one of these pests in the 2011 cropping season, with only a small difference between fields owned by farmers from villages along forests (68\%) and away from (58\%) forest edges (Table 5). However, there was a big difference in the level of damage these pests caused in villages close to and away from forest edges. For example, most of the interviewed farmers $(85 \%)$ close to the forest perceived the damage caused to their maize fields by mainly bush pigs, baboons, and common monkeys as severe/big (a loss of more than a tenth of total yield was considered as severe). A minority of farmers (22\%) living away from forest edges reported similar levels of damage to their maize from mainly bush pigs and common monkeys. This difference is statistically significant ( $\mathrm{p}<0.0001$; Table 5). A 65 -year-old man in Maru village, interviewed in June 2011, stated that "two maize fields which belong to two different owners were completely damaged by bush pigs overnight." It was common to hear such stories in villages along forest edges during cropping seasons. Consequently, the labor demand to mitigate against crop damage is significant and implies that all grown-up family members engaged in continuous protection (day and night) of crops from the first day of sowing until they put the harvest into granaries.

Apart from protecting fields from crop raiding mammals, farmers in the area also used other strategies to mitigate and adapt to this problem. Three other strategies that were repeatedly highlighted by farmers in interviews were: (1) migrating to areas with potential for forest clearing to distance crop fields from forests; (2) allowing immigrants to settle along forest edges where the problems of crop raiding are most severe; and (3) removing trees from annual crop fields to facilitate plowing, meeting domestic wood demands, and reducing the opportunities for monkeys to find shelter in crop fields. 
Table 5. Issues related to farmers' management of ecosystem disservices from and related to trees and forest (in 2011). f: Villages located far from forest edge. n: Villages located along forest edge. N: Sample size of farmers per village or number of fields per land-use type from which the percentages were calculated. ${ }^{\dagger}$ A relative estimate or report by farmers that ranges from more than a tenth to as high as over half of the total yields loss to pest raids. "Tree removal” refers to an act in which farmers removed certain trees from existing fields and incorporated into existing fields or converted forest to agricultural land.

\begin{tabular}{|c|c|c|c|c|}
\hline \multirow[t]{2}{*}{ Village } & \multicolumn{4}{|c|}{$\begin{array}{c}\text { Issues related to management of ecosystem disservices (wild mammal attacks, migration, tree } \\
\text { removal) }\end{array}$} \\
\hline & $\begin{array}{l}\% \text { of fields visited } \\
\text { at least by one } \\
\text { type of wild } \\
\text { mammal }\end{array}$ & $\begin{array}{l}\% \text { of farmers who } \\
\text { reported severe/big loss }{ }^{\dagger} \\
\text { of maize yield due to wild } \\
\text { mammals } \\
(\mathrm{N}=9 \text { per village })\end{array}$ & $\begin{array}{c}\% \text { of the interviewed } \\
\text { farmers identified as } \\
\text { migrants } \\
(\mathrm{N}=9 \text { per village })\end{array}$ & $\begin{array}{l}\% \text { farmers who removed } \\
\text { trees }{ }^{\ddagger} \text { from at least one } \\
\text { of their fields in the } \\
\text { past } 5-10 \text { years } \\
(\mathrm{N}=9 \text { per village })\end{array}$ \\
\hline Doyyo (n) & $69.1(\mathrm{~N}=55)$ & 77.8 & 33.3 & 44.4 \\
\hline Hertanno (f) & $51.9(\mathrm{~N}=52)$ & 11.1 & 55.6 & 33.3 \\
\hline Kerebe (n) & $63.3(\mathrm{~N}=60)$ & 77.8 & 55.6 & 66.7 \\
\hline Kersa (f) & $60.7(\mathrm{~N}=61)$ & 44.4 & 33.3 & 33.3 \\
\hline Kutture (f) & $59.4(\mathrm{~N}=64)$ & 11.1 & 11.1 & 44.4 \\
\hline Maru (n) & $71.9(\mathrm{~N}=57)$ & 100 & 55.6 & 55.6 \\
\hline Villages along forest edge & $68.0(\mathrm{~N}=172)$ & 85.2 & 48.1 & 55.6 \\
\hline $\begin{array}{l}\text { Villages located far from forest } \\
\text { edge }\end{array}$ & $57.6(\mathrm{~N}=177)$ & 22.2 & 33.3 & 37.0 \\
\hline Total & $62.8(\mathrm{~N}=349)$ & 53.7 & 40.7 & 46.3 \\
\hline $\begin{array}{l}\text { Chi-square for villages along } \\
\text { forests vs. far from forest edge }\end{array}$ & 2.655 & 19.068 & 0.690 & 1.192 \\
\hline $\begin{array}{l}\text { P-value for villages along forest vs. } \\
\text { far from forest edge }\end{array}$ & 0.103 & $<0.0001$ & 0.406 & 0.275 \\
\hline
\end{tabular}

\section{Migrating to be able to clear forests}

In the recent past, farmers in Gera have frequently moved within the district to acquire land, including forest land, in different locations, in part because of damage caused by wild mammal pests as described during focus group discussions and interviews. Of the interviewed farmers, $41 \%$ reported that they had migrated to where they resided at the time of the interview. A telling example was when about $60 \%$ of a total of 150 households in Garanaso kebele migrated to kebeles in the higher altitude lands of Gera such as Dusta and Muje during the late 1970s (Fig. 1). According to informants who participated in a focus group discussion held in March 2012 in Garanaso, a chain of factors related to pests, low cereal yield, and market problems were reported as reasons for the migration. Prior to migrating, they had engaged in coffee, honey, maize, sorghum, and livestock production. Part of the maize and sorghum that survived the bad weather in the 1977/8 cropping season was lost to wild mammal pests and that left most farmers empty-handed. As the prices of coffee, honey, and livestock were low while the price of cereals in local markets increased, subsisting on purchased food was difficult. These factors fueled farmers' frustration with pests and their inability to clear the nearby forest, which contained semimanaged forest coffee, to distance their agricultural fields from pests, so a decision to migrate was made. Although forest covered large parts of the kebeles to which they migrated, the migrants knew that it would be possible to clear these forests, because they did not contain coffee, and that other migrants had already started to clear land in this area. Overall, this migration contributed to a fairly rapid transformation, from forest to arable land, and during fieldwork farmers growing cereals and pulses in Dusta and Muje, i.e.,
Kutture and Hertanno villages, respectively, reported low levels of damage by wild mammal pests.

Allowing immigrants to settle along forest edges

According to farmers, there has been frequent immigration of people from different parts of the country to Gera because of the perceived availability of abundant fertile land in the district. During the interviews and focus group discussions, farmers frequently highlighted the immigration and settlement of many immigrants on the forest edges, in many cases by clearing land for cultivation. This had effectively distanced forests and related pests from the crop fields of local residents and early settlers, who considered this process as a positive development because pests posed a substantial problem to living just next to the forest.

\section{Removing trees from crop fields}

Another strategy that farmers reported to have a positive effect on reducing attacks from mammal crop pests, specifically monkeys that shelter in scattered trees, was to remove trees from arable fields. Of the interviewed farmers, $46 \%$ reported that they had removed trees over the past 5 to 10 years from at least one of their fields (Table 5). In villages along forest edges, the most frequently mentioned reason why trees were removed from arable fields was to create open fields, an attempt to create better conditions for plowing, reducing competition for sunlight, and diminishing pest attacks. In villages away from forest, this reason was less frequently mentioned, a difference that was statistically significant (Fig. 7; $p=0.005$ ). Close to forests, farmers frequently reported that "trees died naturally," meaning that trees were injured by debarking, burning, plowing, and cutting to 
systematically remove trees from arable lands (Fig. 8), a practice reflecting that it is illegal to cut naturally grown trees without permission in Ethiopia. In villages away from forest edges, unlike those on the edges, the most frequently mentioned reason why trees were removed from crop fields over the past 5 to 10 years was to meet domestic wood demands (Fig. 7; $p=0.013$ ).

Fig. 7. Major reasons reported by farmers for removing trees in agricultural fields over the past 5 to 10 years. The numbers of fields were pooled data (frequency) for villages close to and away from forest edges, separately.

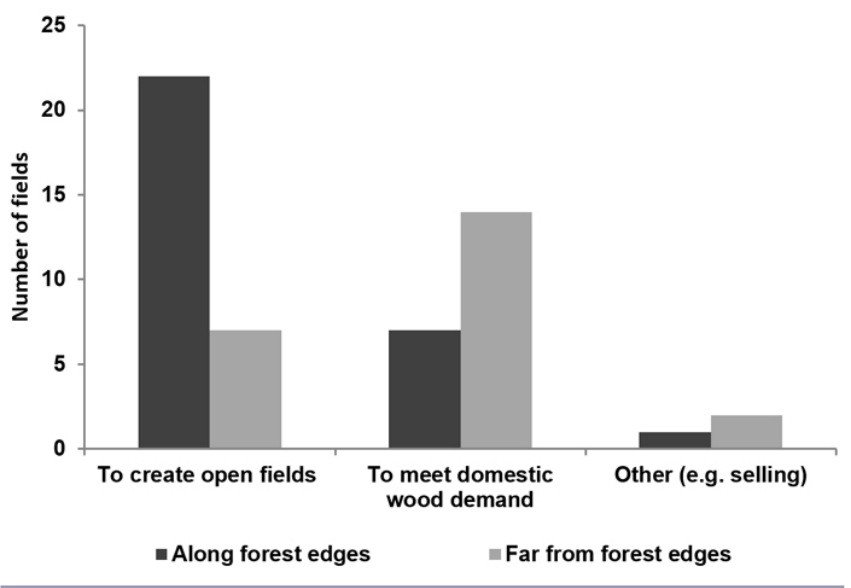

Fig. 8. Different coping strategies practiced by farmers to remove trees from agricultural fields to mitigate ecosystem disservices: (A) debarking, (B) partial cutting, (C) fire, and (D) plowing.

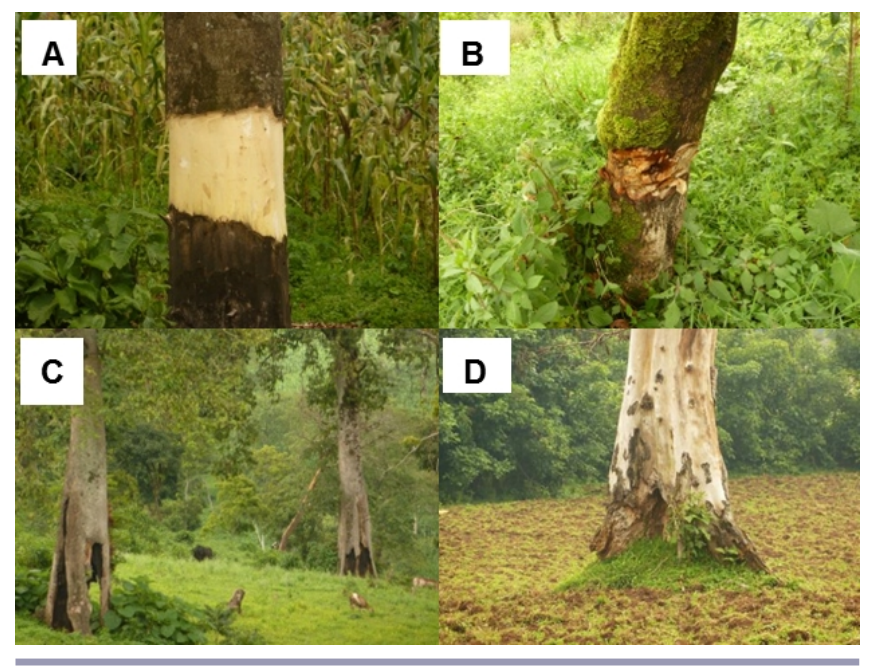

\section{DISCUSSION}

Farmers' management of forest and trees in agricultural land to augment ecosystem services and mitigate disservices

There is relatively good documentation of farmers' management of trees in and around homesteads and on agricultural lands to obtain various benefits (Dewees 1995, Negash 2007, Tolera et al. 2008) such as live fences (Budowski 1987, León and Harvey 2006, Pulido-Santacruz and Renjifo 2011), grazing lands (Harvey and Haber 1999, Harvey et al. 2011), and shade trees for coffee production (Perfecto et al. 1996, Muleta et al. 2011, Borkhataria et al. 2012). However, these studies of farmers' management of trees for their services have not explicitly addressed farmers' perceptions and management of the associated disservices. As our study shows, farmers' perceptions of disservices were as important as services in shaping tree management in agricultural landscapes. Planting and/or retaining of trees inside and/or along field boundaries on different land uses or removal of trees, and farmers' involvement in processes that imply removal of forest and trees, such as migration and allocating migrants on forest edges, were found to be management practices and processes that augmented services from trees and mitigated associated disservices.

Our findings show that (1) farmers planted more tree species along boundaries of cropland and home gardens compared with inside those fields (Figs. 2 and 4); (2) more tree species were retained inside grazing land than along boundaries (Fig. 3) and semimanaged forest coffee lands, which were also the land uses in which fewer disservices were anticipated from trees; and (3) most farmers frequently managed only a few tree species (Fig. 5). The preponderance of planted tree species along field boundaries as live fencing, and retained tree species on grazing land and coffee lands to meet farmers' demands for wood and provide shade reflects the management of preferred trees for specific purposes.

In villages where a variety of benefits, but few and only minor disservices were anticipated from trees, farmers retained and/or planted trees on different land uses, i.e., arable, grazing fields, and home gardens. For example, in Kersa, a village within the coffee growing zone but also far from the forest, farmers reported that trees tended to regrow fast, probably because of the frequent tree patches in and around this village, and that they retained more trees inside cropland, home gardens, and grazing lands, unlike other villages (Figs. 2, 3, 4). However, farmers in Kutture and Hertanno, which lie at a high altitude above the coffee growing zone and far from forests, planted more trees inside grazing land with the intention of meeting their demands for wood (Fig. 3a). The emergence of woodlots with exotic trees in villages away from forest also represents farmers' practice to get trees back in landscapes where more benefits and fewer or no disservices were anticipated (Table 1).

Farmers' perceptions of crop raiding wild mammals have been shown to negatively influence wildlife and forests conservation (e.g., Weladji and Tchamba 2003, Wang et al. 2006). Similarly, our results show that ecosystem disservices (wild mammals) related to forest and trees, required farmers to engage in different processes and mitigation strategies. Examples were the migration within Gera to be able to clear forests (Table 5), the allocation of migrants on forest edges, and removal of trees especially from arable lands (Table 5, Fig. 7) that contributed to tree and forest cover decline. These processes were most prominent in villages along forest edges and outside the coffee growing parts of Gera. Farmers' perceptions and decisions to engage in such activities 
and processes were shaped by their experiences of substantial crop raids by wild mammals.

Taken together, the various processes and forest and tree management strategies with regard to the associated services and disservices discussed in this article represent farmers' efforts to balance the trade-offs between the positives and negatives of having or not having trees on their fields. As a result, farmers engage in an ongoing restructuring of the locations of the preferred tree species in the landscape. The restructuring of trees on agricultural land through removal, retaining, and planting in effect represents a process of "ecological intensification' (Bommarco et al. 2013) that increases or at least maintains the benefits or productive value that farmers receive from trees (Pimentel et al. 1992, Thrupp 2000, Altieri and Koohafkan 2008), including mitigation of disservices. Put differently, the managed trees represent an enduring modification in the landscape or an investment in "landesque capital" (Blaikie and Brookfield 1987, Brookfield 2001, Börjeson 2014). The extent of landscape restructuring and the resulting balance of the trade-offs between services and disservices varies, based on the specific geographical context such as altitude and distance to forests. In relation to this, three main restructuring processes emerged as farmers decided to remove, retain, and/or plant trees in places where the trees could provide services and where associated disservices were minimized:

1. At high altitude, above the coffee growth zone, close to forests, farmers mainly manage the landscape to mitigate disservices by removing trees from arable fields and from grazing land that mostly buffers croplands and home garden from forest and associated pests (e.g., Fig. 3c, Maru village). Trees on agricultural lands were mostly preferred as live fences.

2. In the coffee growing altitude zone, close to forests, farmers struggle with balancing services and disservices by employing a mix of strategies: live fencing, keeping a few trees in arable fields, managing shade trees for coffee, and long hours of guarding against pests.

3. Away from forests, both in coffee and noncoffee growing zones, farmers manage to preserve services from trees by keeping woodlots, live fencing, and shade trees (in Kersa), resulting in a reforestation process. In line with our findings, others studies have documented, for example, how farmers' tree and forest management for shade coffee production drives afforestation and deforestation (Hylander et al. 2013), and how farmers' management of trees in pastureland affects tree cover (Harvey et al. 2011).

It is clear from our study that farmers' perceptions of services and disservices from and related to forest and trees, as well as the management practices required to balance them have contributed to shape the spatial pattern and the composition of trees in the agricultural landscape. A number of studies have documented the contributions of trees and forests in mosaic agricultural landscape in providing provisioning ecosystem services (food, fodder, and fiber) as well as regulation of soil fertility, water, and climate regulation (Zhang et al. 2007, Power 2010, Smukler et al. 2012), and in supporting biodiversity conservation through enhancement of landscape connectivity by live fences, shade trees in home gardens, and trees in grazing lands (Manning et al. 2006, Fischer et al. 2010, Perfecto and Vandermeer 2010, PulidoSantacruz and Renjifo 2011). However, based on our study, we find a need for studies that also account for perceptions, management practices, and processes related to how farmers balance services and disservices from trees and forests, and how this contributes to shaping agricultural landscape mosaics.

\section{Implications of current tree management practices for future tree cover}

As our results show, the demand for shade trees for coffee production is the major factor in maintaining trees preferred for shade in the coffee growing part of the district. As shown by a recent study, coffee production has clearly regulated the distribution of forest canopy cover change in the region over the past 40 years (Hylander et al. 2013). With growing human and livestock pressure on permanent grazing lands, live fencing can be expected to expand, even in areas where it is currently less practiced, such as Kersa and Kerebe (Table 3). In Kersa, there is still some communal grazing land, though its size has been dwindling over time, whereas the last communal grazing land was privatized less than a decade ago in Kerebe, which could necessitate the construction of more live fences mainly to keep livestock away from crops. With agricultural intensification i.e., conversion of grazing land to croplands and reduction or elimination of fallow periods, retained trees in cropland could possibly decrease. Last, there is also a possibility for the expansion of woodlots of exotic tree species such as Eucalyptus because of increasing demand for various wood products while access to the state-owned forest to meet such demands has been declining (T. G. Ango, personal observation). Compared with naturally grown trees, farmers are not required to get permission from the kebele administration when they want to cut Eucalyptus. This is because in recent years the Ethiopian government has strongly discouraged the expansion of Eucalyptus trees because of the alleged negative ecological consequences (Chanie et al. 2013). Because farmers find it an important tree that grows fast and provides valuable wood products, both for home consumption and the market, the Eucalyptus is now one of the most frequently planted trees in many parts of Ethiopia (Wirtu 1998, Jenbere 2009, Ango 2010). In addition to eucalyptus, permission is not required to cut planted tree species that are mainly used for live fences, such as Erythrina sp. and Euphorbia ampliphylla, which might further enhance the expansion of live fencing. This shows the impact of tenure rights on farmers' decisions and management practices related to trees (Admassie 2000, Yin and Hyde 2000), and that more live fencing and shade trees managed in home gardens, and on coffee land, as well as more wood lots, mostly exotic, and state-owned forest are all expected to be part of the future Gera landscape mosaic.

\section{Usefulness of operationalizing ecosystem services as services and disservices}

Our interdisciplinary investigation of farmers' management practices with regard to forest and trees in an agricultural landscape, based on the concept of ecosystem services and disservices, aligns well with how farmers conceive and engage with nature in relation to their livelihoods. This approach has enabled us to understand the choices farmers face and their perceptions and resulting practices and processes in relation to the studied ecosystem components. 
Hence, on the basis of our study and related literature (cf. Lyytimäki et al. 2008, Dunn 2010), we propose that the usefulness of the concept of ecosystem services for studies of farmers' management practices can be improved if ecosystem processes are explicitly operationalized as disservices and services, in addition to studying trade-offs between different ecosystem services. Such an operationalization can improve understandings of how local land users perceive and manage different ecosystem components in agricultural landscapes. When operationalized as services and disservices, the ecosystem service framework, we argue, becomes a more relevant and useful heuristic tool (cf. Hodgson et al. 2007, Fish 2011, Tuvendal 2012) for investigations of local practices and farmers' engagements with nature.

\section{CONCLUSIONS}

Tropical agricultural landscapes are generally valued for providing diverse ecosystem services, including protecting biodiversity, in addition to supporting local livelihoods. In this study, which employed mixed methods, we investigated how farmers' management practices were based on their perceptions and evaluations of the direct and associated services and disservices that trees and forest provide to local livelihoods and agricultural production. Our findings show that farmers' management practices were geared toward augmenting services and reducing disservices from and related to trees and forest, resulting in a restructuring of the agroecosystem, i.e., tree removal and restructuring the locations of the preferred tree species. Understanding management practices and processes is fundamental to appreciating the challenges and opportunities for biodiversity conservation in agricultural landscapes. The operationalizing of ecosystem services as disservices and services is therefore important, not least in empirical studies related to agricultural landscapes, to understand the interrelated dynamics, trade-offs, and management from the perspective of local farmers.

Responses to this article can be read online at: http://www.ecologyandsociety.org/issues/responses. $\mathrm{php} / 6279$

\section{Acknowledgments:}

We are grateful to all farmers for sharing their lived experiences with us. We also appreciate the unreserved support we received from our field assistants and staff at different administration offices at District and kebele levels in Gera. The research was funded by grants from the Swedish International Development Cooperation Agency (Sida; contract number: SWE-2009-134) and the Swedish Research Council Formas (contract number: 229-2009-991) to Kristoffer Hylander. We acknowledge the anonymous reviewers for their insights and useful comments.

\section{LITERATURE CITED}

Admassie, Y. 2000. Twenty years to nowhere: property rights, land management and conservation in Ethiopia. Red Sea Press, Lawrenceville, New Jersey, USA.

Altieri, M. A., and P. Koohafkan. 2008. Enduring farms: climate change, smallholders and traditional farming communities.
Environment and development Series 6, Third World Network, Penang, Malaysia. [online] URL: http://www.fao.org/nr/water/ docs/Enduring Farms.pdf

Ango, T. G. 2010. Expansion of eucalyptus plantations by smallholder farmers amid natural forest depletion: case study from Mulo District in Central Oromia. Pages 335-350 in L. Gil, W. Tadesse, E. Tolosana, and R. Lopez, editors. Proceeding of the conference on Eucalyptus species, management, history, status and trends in Ethiopia 15-17 September 2010. Ethiopian Institute of Agricultural Research, Addis Ababa, Ethiopia.

Årlin, C., L. Börjeson, and W. Östberg. In press. Participatory checking and the temporality of landscapes: increasing trust and relevance in qualitative research. In C. Isendahl and D. Stump, editors. Oxford handbook of historical ecology and applied archaeology. Oxford University Press, Oxford, UK.

Bhagwat, S. A., K. J. Willis, H. J. B. Birks, and R. J. Whittaker. 2008. Agroforestry: a refuge for tropical biodiversity? Trends in Ecology \& Evolution 23(5):261-267. http://dx.doi.org/10.1016/j. tree.2008.01.005

Blaikie, P., and H. Brookfield. 1987. Land degradation and society. Routledge, New York, New York, USA.

Bommarco, R., D. Kleijn, and S. G. Potts. 2013. Ecological intensification: harnessing ecosystem services for food security. Trends in Ecology \& Evolution 28(4):230-238. http://dx.doi. org/10.1016/j.tree.2012.10.012

Börjeson, L. 2014. The antithesis of degraded land: toward a greener conceptualization of landesque capital. In N. T. Håkansson and M. Widgren, editors. Landesque capital: the historical ecology of enduring landscape modifications. Left Coast Press, Walnut Creek, California, USA.

Borkhataria, R., J. A. Collazo, M. J. Groom, and A. J. Garcia. 2012. Shade-grown coffee in Puerto Rico: opportunities to preserve biodiversity while reinvigorating a struggling agricultural commodity. Agriculture, Ecosystems \& Environment 149:164-170. http://dx.doi.org/10.1016/j.agee.2010.12.023

Brookfield, H. 2001. Exploring agrodiversity. Columbia University Press, New York, New York, USA.

Budowski, G. 1987. Living fences in tropical America, a widespread agroforestry practice. Pages $169-178$ in H. L. Gholz, editor. Agroforestry: realities, possibilities and potentials. Martinus Nijhoff, Dordrecht, The Netherlands.

Central Statistical Authority (CSA). 1996. The 1994 population and housing census of Ethiopia: statistical report on population size and characteristics for Oromia Region I (II). CSA, Addis Ababa, Ethiopia.

Central Statistical Authority (CSA). 2012. Ethiopia statistical abstract: population. CSA, Addis Ababa, Ethiopia. [online] URL: http://www.csa.gov.et/images/documents/pdf files/ nationalstatisticsabstract/2012/2012\%20POPULATION.pdf

Chanie, T., A. S. Collick, E. Adgo, C. J. Lehmann, and T. S. Steenhuis. 2013. Eco-hydrological impacts of Eucalyptus in the semi-humid Ethiopian highlands: the Lake Tana plain. Journal of Hydrology and Hydromechanics 61(1):21-29. http://dx.doi. org/10.2478/johh-2013-0004 
Daily, G. C. 1997. Introduction: what are ecosystem services? Pages 1-10 in G. C. Daily, editor. Nature's services: societal dependence on natural ecosystem. Island, Washington, D.C., USA.

Daily. G. C., S. Polasky, J. Goldstein, P. M. Kareiva, H. A. Mooney, L. Pejchar, T. H. Ricketts, J. Salzman, and R. Shallenberger. 2009. Ecosystem services in decision making: time to deliver. Frontiers in Ecology and the Environment 7:21-28. http:// dx.doi.org/10.1890/080025

Dewees, P. A. 1995. Trees on farms in Malawi: private investment, public policy, and farmer choice. World Development 23 (7):1085-1102. http://dx.doi.org/10.1016/0305-750X(95)00034-A

Dufrêne, M., and P. Legendre. 1997. Species assemblages and indicator species: the need for a flexible asymmetrical approach. Ecological Monographs 67(3):345-366. http://dx.doi.org/10.2307/2963459

Dunn, R. R. 2010. Global mapping of ecosystem disservices: the unspoken reality that nature sometimes kills us. Biotropica 42 (5):555-557. http://dx.doi.org/10.1111/j.1744-7429.2010.00698.x

Elwood, S. 2010. Mixed methods: thinking, doing, and asking in multiple ways. Pages 94-115 in D. DeLyser, S. Herbert, S. C. Aitken, M. Crang, and L. McDowell, editors. The SAGE handbook of qualitative geography. SAGE, Los Angeles, California, USA. http://dx.doi.org/10.4135/9780857021090.n7

Engeman, R. M., J. E. Laborde, B. U. Constantin, S. A. Shwiff, P. Hall, A. Duffiney, and F. Luciano. 2010. The economic impacts to commercial farms from invasive monkeys in Puerto Rico. Crop Protection 29:401-405. http://dx.doi.org/10.1016/j.cropro.2009.10.021

Escobedo, F. J., T. Kroeger, and J. E. Wagner. 2011. Urban forests and pollution mitigation: analyzing ecosystem services and disservices. Environmental Pollution 159:2078-2087. http://dx.doi. org/10.1016/j.envpol.2011.01.010

Fischer, J., J. Stott, and B. S. Law. 2010. The disproportionate value of scattered trees. Biological Conservation 143 (6):1564-1567. http://dx.doi.org/10.1016/j.biocon.2010.03.030

Fish, R. D. 2011. Environmental decision making and an ecosystems approach: some challenges from the perspective of social science. Progress in Physical Geography 35(5):671-680. http://dx.doi.org/10.1177/0309133311420941

Gómez-Baggethun, E., R. de Groot, P. L. Lomas, and C. Montes. 2010. The history of ecosystem services in economic theory and practice: from early notions to markets and payment schemes. Ecological Economics 69(6):1209-1218. http://dx.doi.org/10.1016/ j.ecolecon.2009.11.007

Harvey, C. A., and W. A. Haber.1999. Remnant trees and the conservation of biodiversity in Costa Rican pastures. Agroforestry Systems 44(1):37-68. http://dx.doi.org/10.1023/ $\underline{\mathrm{A}: 1006122211692}$

Harvey, C. A., C. Villanueva, H. Esquivel, R. Gómez, M. Ibrahim, M. Lopez, J. Martinez, D. Muñoz, C. Restrepo, J. C. Saénz, J. Villacís, and F. L. Sinclair. 2011. Conservation value of dispersed tree cover threatened by pasture management. Forest Ecology and Management 261(10):1664-1674. http://dx.doi.org/10.1016/j. foreco.2010.11.004
Harvey, C. A., C. Villanueva, J. Villacís, M. Chacón, D. Muňoz, M. López, M. Ibrahim, R. Gómez, R. Taylor, J. Martinez, A. Navas, J. Saenz, D. Sánchez, A. Medina, S. Vilchez, B. Hernández, A. Perez, F. Ruiz, F. López, I. Lang, and F. L. Sinclair. 2005. Contribution of live fences to the ecological integrity of agricultural landscapes. Agriculture, Ecosystems \& Environment 111:200-230. http://dx.doi.org/10.1016/j.agee.2005.06.011

Hassen, M. 1990. The Oromo of Ethiopia: a history 1570-1860. Cambridge University Press, New York, New York, USA.

Hodgson, S. M., L. Maltby, A. Paetzold, and D. Phllips. 2007. Getting a measure of nature: cultures and values in an ecosystem services approach. Interdisciplinary Science Reviews 32 (3):249-262. http://dx.doi.org/10.1179/030801807X211739

Hylander, K., S. Nemomissa, J. Delrue, and W. Enkosa. 2013. Effects of coffee management on deforestation rates and forest integrity. Conservation Biology 27(5):1031-1040. http://dx.doi. org/10.1111/cobi.12079

Jenbere, D. 2009. The expansion of eucalyptus plantation by smallholder farmers and its drivers: the case of Arsi Negelle District, Southern Oromia, Ethiopia. Thesis, Wondo Genet College of Forestry and Natural Resources, Wondo Genet, Ethiopia.

Lemessa, D., K. Hylander, and P. Hambäck. 2013. Composition of crops and land-use types in relation to crop raiding pattern at different distances from forests. Agriculture, Ecosystems \& Environment 167:71-78. http://dx.doi.org/10.1016/j.agee.2012.12.014

León, M. C., and C. A. Harvey. 2006. Live fences and landscape connectivity in a Neotropical agricultural landscape. Agroforestry Systems 68(1):15-26. http://dx.doi.org/10.1007/s10457-005-5831-5

Liu, J., S. Li, Z. Ouyang, C. Tam, and X. Chen. 2008. Ecological and socioeconomic effects of China's policies for ecosystem services. Proceedings of the National Academy of Sciences of the United States of America 105(28):9477-9482. http://dx.doi. org/10.1073/pnas.0706436105

Lyytimäki, J., L. K. Petersen, B. Normander, and P. Bezák. 2008. Nature as a nuisance? Ecosystem services and disservices to urban lifestyle. Environmental Sciences 5(3):161-172. http://dx.doi. org/10.1080/15693430802055524

Lyytimäki, J., and M. Sipilä. 2009. Hoping on one leg - the challenge of ecosystem disservices for urban green management. Urban Forestry \& Urban Greening 8(4):309-315. http://dx.doi. org/10.1016/j.ufug.2009.09.003

Manning, A. D., J. Fischer, and B. Lindenmayer. 2006. Scattered trees are keystone structures - implications for conservation. Biological Conservation 132(3):311-321. http://dx.doi.org/10.1016/ j.biocon.2006.04.023

McCune, B., and M. J. Mefford. 2006. PC-ORD. Multivariate analysis of ecological data. Version 5.10. MjM Software, Gleneden Beach, Oregon, USA.

Millennium Ecosystem Assessment (MA). 2005. Ecosystems and human well-being: synthesis. Island, Washington, D.C., USA. [online] URL: http://www.unep.org/maweb/documents/document.356. aspx.pdf 
Muleta D., F. Assefa, S. Nemomissa, and U. Granhall. 2011. Socioeconomic benefits of shade trees in coffee production systems in Bonga and Yayuhumuru districts, Southwestern Ethiopia: farmers' perceptions. Ethiopian Journal of Education and Sciences 7(1):39-56. [online] URL: http://www.ajol.info/ index.php/ejesc/article/viewFile/75503/66045

Negash, M. 2007. Trees management and livelihoods in Gedeo's agroforests, Ethiopia. Forests, Trees and Livelihoods 17 (2):157-168. http://dx.doi.org/10.1080/14728028.2007.9752591

Norgaard, R. B. 2010. Ecosystem services: from eye-opening metaphor to complexity blinder. Ecological Economic Economics 69(6):1219-1227. http://dx.doi.org/10.1016/j.ecolecon.2009.11.009

O'Farrell, P. J., J. S. Donaldson, and M. T. Hoffman. 2007. The influence of ecosystem goods and services on livestock management practices on the Bokkeveld plateau, South Africa. Agriculture, Ecosystems \& Environment 122(3):312-324. http://dx. doi.org/10.1016/j.agee.2007.01.025

Perfecto, I., R. A. Rice, R. Greenberg, and M. E. Van der Voort. 1996. Shade coffee: a disappearing refuge for biodiversity. BioScience 46(8):598-608. http://dx.doi.org/10.2307/1312989

Perfecto, I., and J. Vandermeer. 2008. Biodiversity conservation in tropical agroecosystems: a new conservation paradigm. Annals of the New York Academy of Sciences 1134:173-200. http://dx.doi. org/10.1196/annals.1439.011

Perfecto, I., and J. Vandermeer. 2010. The agroecological matrix as alternative to land-sparing/agricultural intensification model. Proceedings of the National Academy of Sciences of the United States of America 107(13):5786-5791. http://dx.doi.org/10.1073/ pnas.0905455107

Pimentel, D., U. Stachow, D. A. Takacs, H. W. Brubaker, A. R. Dumas, J. J. Meaney, J. A. S. O’Neil, D. E. Onsi, and D. B. Corzilius. 1992. Conserving biological diversity in agricultural/ forestry systems. BioScience 42(5):354-362. http://dx.doi. org/10.2307/1311782

Power, A. G. 2010. Ecosystem services and agriculture: tradeoffs and synergies. Philosophical Transactions of the Royal Society B 365:2959-2971. http://dx.doi.org/10.1098/rstb.2010.0143

Pulido-Santacruz, P., and L. M. Renjifo. 2011. Live fences as tools for biodiversity conservation: a study case with birds and plants. Agroforestry Systems 81:15-30. http://dx.doi.org/10.1007/ s10457-010-9331-X

R Development Core Team. 2010. A language and environment for statistical computing. R Foundation for Statistical Computing, Vienna, Austria. ISBN 3-900051-07-0. [online] URL: http://www. R-project.org/

Rodríguez, J. P., T. D. Beard, Jr., E. M. Bennett, G. S. Cumming, S. Cork, J. Agard, A. P. Dobson, and G. D. Peterson. 2006. Tradeoffs across space, time, and ecosystem services. Ecology and Society 11(1): 28. [online] URL: http://www.ecologyandsociety. org/vol11/iss1/art28/

Smukler, S. M., S. M. Philpott, L. E. Jackson, A.-M. Klein, F. DeClerck, L. Winowiecki, and C. A. Palm. 2012. Ecosystem services in agricultural landscapes. Pages 17-51 in J. C. Ingram, F. DeClerck, C. R. d. Rio, editors. Integrating ecology and poverty reduction: ecological dimensions. Springer, New York, New York, USA. http://dx.doi.org/10.1007/978-1-4419-0633-5_3

Thrupp, L. A. 2000. Linking agricultural biodiversity and food security: the valuable role of agrobiodiversity for sustainable agriculture. International Affairs 76(2):265-281. http://dx.doi. org/10.1111/1468-2346.00133

Tolera, M., Z. Asfaw, M. Lemenih, and E. Karltun. 2008. Woody species diversity in a changing landscape in the south-central highlands of Ethiopia. Agriculture, Ecosystems \& Environment. 128:52-58. http://dx.doi.org/10.1016/j.agee.2008.05.001

Tuvendal, M. 2012. Ecosystem services: a tool in sustainable landscape management. Dissertation. Stockholm University, Stockholm, Sweden.

Wang, S. W., P. D. Curtis, and J. P. Lassoie. 2006. Farmer perceptions of crop damage by wildlife in Jigme Singye Wangchuck National Park, Bhutan. Wildlife Society Bulletin 34 (2):359-365. http://dx.doi.org/10.2193/0091-7648(2006)34[359: FPOCDB]2.0.CO;2

Weladji, R. B., and M. N. Tchamba. 2003. Conflict between people and protected areas within the Bénoué Wildlife Conservation Area, North Cameroon. Oryx 37(1):72-79. http:// dx.doi.org/10.1017/S0030605303000140

Wirtu, D., 1998. The economics of growing Eucalyptus globulus (Labill.) on the Highlands of Oromia, Ethiopia; with special reference to Intoto and Chancho areas. Thesis. Wondo Genet College of Forestry, Wondo Genet, Ethiopia.

Yin, R., and W. F. Hyde. 2000. Trees as an agriculture sustaining activity: the case of northern China. Agroforestry Systems 50 (2):179-194. http://dx.doi.org/10.1023/A:1006430320381

Zhang, W., T. H. Ricketts, C. Kremen, K. Carney, and S. M. Swinton. 2007. Ecosystem services and dis-services to agriculture. Ecological Economics 64:253-260. http://dx.doi.org/10.1016/j. ecolecon.2007.02.024 


\section{Appendix 1.}

Table A1.1 Indicator species values for trees recorded inside and on boundaries of fields. The table is sorted according to the difference in indicator value, implying that species which are found more inside fields have a positive value, and species found at the boundaries have a negative value.

\begin{tabular}{|c|c|c|c|c|c|c|c|}
\hline \multirow[t]{2}{*}{ Scientific name } & \multirow[t]{2}{*}{ Local name/s } & \multicolumn{2}{|c|}{$\begin{array}{c}\text { No. of fields contained } \\
\text { the species }\end{array}$} & \multicolumn{2}{|c|}{ Indicator value (IV) } & \multirow{2}{*}{$\begin{array}{c}\mathrm{p}- \\
\text { value }\end{array}$} & \multirow{2}{*}{$\begin{array}{l}\text { Difference } \\
(\mathrm{a}-\mathrm{b})\end{array}$} \\
\hline & & Inside & On boundary & Inside (a) & Boundary (b) & & \\
\hline Sesbania sesban & Sasbenia & 7 & 0 & 67 & 0 & 0.060 & 67 \\
\hline Ficus sur & Harbu & 11 & 1 & 61 & 1 & 0.099 & 60 \\
\hline Ricinus communis & Qobo & 7 & 2 & 65 & 7 & 0.170 & 58 \\
\hline Millettia ferruginea & Askira & 57 & 23 & 71 & 29 & 0.036 & 42 \\
\hline Bersama abyssinica & Lolchissa & 17 & 5 & 52 & 11 & 0.306 & 41 \\
\hline Schefflera abyssinica & Botto & 5 & 1 & 42 & 3 & 0.420 & 39 \\
\hline Acacia lahai & Sondi & 9 & 2 & 41 & 3 & 0.426 & 38 \\
\hline Maytenus arbutifolia & Kombolicha & 15 & 8 & 54 & 17 & 0.357 & 37 \\
\hline Brucea antidysenterica & Boqo & 2 & 0 & 33 & 0 & 0.455 & 33 \\
\hline Cassipourea malosana & Barsadi & 2 & 0 & 33 & 0 & 0.464 & 33 \\
\hline Albizia gummifera & Hambabessa & 39 & 20 & 55 & 23 & 0.398 & 32 \\
\hline Vernonia amygdalina & Ibicha & 21 & 10 & 56 & 27 & 0.434 & 29 \\
\hline Acacia abyssinica & Lafto & 19 & 2 & 30 & 3 & 0.577 & 27 \\
\hline Apodytes dimidiata & Wandabiyo & 7 & 1 & 29 & 2 & 0.455 & 27 \\
\hline Phoenix reclinata & Mexi & 5 & 1 & 28 & 3 & 0.455 & 25 \\
\hline Cordia africana $(\mathrm{n})$ & Wadessa & 8 & 2 & 27 & 3 & 0.728 & 24 \\
\hline Syzygium guineense ssp. guineense & Badessa & 14 & 8 & 42 & 18 & 0.494 & 24 \\
\hline Croton macrostachyus & Bakenisa & 38 & 24 & 61 & 39 & 0.267 & 22 \\
\hline Hagenia abyssinica & Heto & 4 & 2 & 33 & 11 & 0.685 & 22 \\
\hline Polyscias fulva (n) & Kariyoo & 7 & 2 & 26 & 4 & 0.717 & 22 \\
\hline Macaranga capensis & Wango & 3 & 1 & 25 & 4 & 0.734 & 21 \\
\hline Alangium chinense (n) & Halale & 1 & 0 & 17 & 0 & 1 & 17 \\
\hline Allophylus macrobotrys (n) & Seyo & 1 & 0 & 17 & 0 & 1 & 17 \\
\hline Diospyros abyssinica (f) & Loko & 1 & 0 & 17 & 0 & 1 & 17 \\
\hline Olinia rochetiana $(\mathrm{n})$ & Sole/qeye & 1 & 0 & 17 & 0 & 1 & 17 \\
\hline Salix subserrata (n) & Aleltu & 1 & 0 & 17 & 0 & 1 & 17 \\
\hline Clerodendrum myricoides & Qorasuma & 2 & 2 & 17 & 8 & 1 & 9 \\
\hline Arundinaria alpina & Leman & 9 & 7 & 28 & 22 & 0.912 & 6 \\
\hline Maesa lanceolata & Abayi & 13 & 8 & 31 & 25 & 0.935 & 6 \\
\hline Grevillea robusta (f) & Gravilla & 1 & 1 & 8 & 8 & 1 & 0 \\
\hline Pouteria adolfi-friederici (f) & Qararo & 2 & 2 & 8 & 8 & 1 & 0 \\
\hline Sapium ellipticum $(\mathrm{n})$ & Bosoqu/Bosoqa & 2 & 2 & 8 & 8 & 1 & 0 \\
\hline Spathodia nilotica (f) & Spatodia & 1 & 1 & 8 & 8 & 1 & 0 \\
\hline Dombeya torrida (f) & Danisa & 5 & 8 & 13 & 21 & 0.846 & -8 \\
\hline Prunus africana & Omo & 10 & 12 & 30 & 45 & 0.701 & -15 \\
\hline Ekebergia capensis & Hororo/sombo & 3 & 6 & 17 & 33 & 0.841 & -16 \\
\hline Dracaena sp. (n) & Emo & 0 & 1 & 0 & 17 & 1 & -17 \\
\hline Fagaropsis angolensis (n) & Sigilu & 0 & 1 & 0 & 17 & 1 & -17 \\
\hline Ficus thonningii $(\mathrm{n})$ & Qilxuu & 0 & 1 & 0 & 17 & 1 & -17 \\
\hline Pinus patula $(\mathrm{n})$ & Pinus & 0 & 2 & 0 & 17 & 1 & -17 \\
\hline Cupressus lusitanica & Xid & 9 & 14 & 33 & 51 & 0.596 & -18 \\
\hline Olea welwitschii (f) & Baya & 1 & 3 & 4 & 25 & 0.723 & -21 \\
\hline Eucalyptus sp. & Bargamo/Barzef & 31 & 51 & 38 & 62 & 0.257 & -24 \\
\hline Pterolobium stellatum (n) & Gora Faranji & 0 & 2 & 0 & 33 & 0.447 & -33 \\
\hline Euphorbia cotinifolia & Ababa dima & 1 & 4 & 3 & 40 & 0.425 & -37 \\
\hline Vernonia auriculifera & Reji & 14 & 33 & 25 & 70 & 0.133 & -45 \\
\hline Justicia schimperiana & Dhumuga & 0 & 7 & 0 & 50 & 0.183 & -50 \\
\hline Erythrina sp. & Bero/welenisu & 6 & 132 & 2 & 96 & 0.002 & -94 \\
\hline Euphorbia ampliphylla & Adami & 5 & 133 & 2 & 96 & 0.003 & -94 \\
\hline
\end{tabular}

$\mathrm{n}$ : Refers to tree species only recorded in the fields owned by farmers living in villages along forest edges (12 in total);

f: Refers to tree species only recorded in the fields owned by farmers living in villages located away from forest edges ( 6 in total). All other trees species were recorded both in fields used by farmers living in villages close to and away from forest edges ( 31 in total).

- A total of 49 (43 in fields used by farmers living close to and 37 in fields away from forest edges) tree species were recorded in the lands used by the sample households.

- Fruit trees that are common in the home gardens of most of the interviewed farmers, in all villages, are not included in this list. 


\section{Appendix 2.}

Table A2.1. Number of surveyed fields that contained tree species inside and/or on boundaries in the six villages ${ }^{\dagger}$.

\begin{tabular}{|c|c|c|c|c|c|c|c|c|c|c|c|c|}
\hline \multirow{3}{*}{ Species name } & \multicolumn{12}{|c|}{ Number of fields } \\
\hline & \multicolumn{2}{|c|}{ Kutture } & \multicolumn{2}{|c|}{ Kerebe } & \multicolumn{2}{|c|}{ Doyyo } & \multicolumn{2}{|c|}{ Kersa } & \multicolumn{2}{|c|}{ Maru } & \multicolumn{2}{|c|}{ Hertanno } \\
\hline & I & $\mathrm{B}$ & I & $\mathrm{B}$ & I & $\mathrm{B}$ & I & B & I & $\mathrm{B}$ & I & $\mathrm{B}$ \\
\hline Acacia lahai & 0 & 0 & 2 & 0 & 1 & 0 & 6 & 2 & 0 & 0 & 0 & 0 \\
\hline Acacia abyssinica & 0 & 0 & 6 & 1 & 0 & 0 & 13 & 1 & 0 & 0 & 0 & 0 \\
\hline Alangium chinense & 0 & 0 & 0 & 0 & 1 & 0 & 0 & 0 & 0 & 0 & 0 & 0 \\
\hline Albizia gummifera & 1 & 1 & 5 & 4 & 13 & 12 & 19 & 3 & 1 & 0 & 0 & 0 \\
\hline Allophylus macrobotrys & 0 & 0 & 0 & 0 & 0 & 0 & 0 & 0 & 1 & 0 & 0 & 0 \\
\hline Apodytes dimidiata & 3 & 1 & 0 & 0 & 4 & 0 & 0 & 0 & 0 & 0 & 0 & 0 \\
\hline Arudinaria alpina & 5 & 2 & 0 & 0 & 0 & 0 & 0 & 0 & 1 & 3 & 3 & 2 \\
\hline Bersama abyssinica & 2 & 1 & 0 & 0 & 3 & 0 & 0 & 0 & 10 & 3 & 2 & 1 \\
\hline Brucea antidysenterica & 0 & 0 & 1 & 0 & 0 & 0 & 1 & 0 & 0 & 0 & 0 & 0 \\
\hline Cassipourea malosana & 0 & 0 & 0 & 0 & 0 & 0 & 0 & 0 & 1 & 0 & 1 & 0 \\
\hline Clerodendrum myricoides & 0 & 0 & 1 & 2 & 0 & 0 & 1 & 0 & 0 & 0 & 0 & 0 \\
\hline Cordia africana & 0 & 0 & 2 & 0 & 6 & 2 & 0 & 0 & 0 & 0 & 0 & 0 \\
\hline Croton macrostachyus & 3 & 4 & 4 & 1 & 8 & 3 & 4 & 2 & 9 & 10 & 10 & 4 \\
\hline Cupressus lusitanica & 3 & 1 & 0 & 4 & 1 & 2 & 1 & 2 & 1 & 0 & 3 & 5 \\
\hline Diospyros abyssinica & 1 & 0 & 0 & 0 & 0 & 0 & 0 & 0 & 0 & 0 & 0 & 0 \\
\hline Dombeya torrida & 4 & 5 & 0 & 0 & 0 & 0 & 0 & 0 & 0 & 0 & 1 & 3 \\
\hline Dracaena sp. & 0 & 0 & 0 & 0 & 0 & 1 & 0 & 0 & 0 & 0 & 0 & 0 \\
\hline Ekebergia capensis & 0 & 1 & 1 & 0 & 1 & 0 & 0 & 0 & 0 & 1 & 1 & 4 \\
\hline Erythrina sp. & 1 & 39 & 0 & 18 & 2 & 15 & 3 & 8 & 0 & 27 & 0 & 25 \\
\hline Eucalyptus sp. & 9 & 14 & 3 & 6 & 2 & 3 & 7 & 6 & 3 & 6 & 7 & 16 \\
\hline Euphorbia ampliphylla & 1 & 35 & 1 & 13 & 0 & 24 & 1 & 2 & 0 & 32 & 2 & 27 \\
\hline Euphorbia cotinifolia & 0 & 0 & 0 & 1 & 0 & 1 & 1 & 2 & 0 & 0 & 0 & 0 \\
\hline Fagaropsis angolensis & 0 & 0 & 0 & 0 & 0 & 1 & 0 & 0 & 0 & 0 & 0 & 0 \\
\hline Ficus sur & 3 & 1 & 0 & 0 & 4 & 0 & 0 & 0 & 1 & 0 & 3 & 0 \\
\hline Ficus thonningii & 0 & 0 & 0 & 1 & 0 & 0 & 0 & 0 & 0 & 0 & 0 & 0 \\
\hline Grevillea robusta & 0 & 0 & 0 & 0 & 0 & 0 & 1 & 1 & 0 & 0 & 0 & 0 \\
\hline Hagenia abyssinica & 2 & 1 & 0 & 0 & 1 & 0 & 1 & 1 & 0 & 0 & 0 & 0 \\
\hline Justicia schimperiana & 0 & 0 & 0 & 0 & 0 & 3 & 0 & 0 & 0 & 2 & 0 & 2 \\
\hline Macaranga capensis & 0 & 1 & 1 & 0 & 0 & 0 & 2 & 0 & 0 & 0 & 0 & 0 \\
\hline Maesa lanceolata & 0 & 1 & 4 & 2 & 1 & 2 & 8 & 3 & 0 & 0 & 0 & 0 \\
\hline Maytenus arbutifolia & 0 & 0 & 3 & 3 & 1 & 0 & 8 & 3 & 2 & 2 & 1 & 0 \\
\hline Millettia ferruginea & 9 & 4 & 3 & 1 & 5 & 1 & 14 & 4 & 13 & 6 & 13 & 7 \\
\hline Olea welwitschii & 0 & 1 & 0 & 0 & 0 & 0 & 1 & 2 & 0 & 0 & 0 & 0 \\
\hline Olinia rochetiana & 0 & 0 & 0 & 0 & 1 & 0 & 0 & 0 & 0 & 0 & 0 & 0 \\
\hline Phoenix reclinata & 0 & 0 & 2 & 1 & 0 & 0 & 3 & 0 & 0 & 0 & 0 & 0 \\
\hline Pinus pastula & 0 & 0 & 0 & 0 & 0 & 2 & 0 & 0 & 0 & 0 & 0 & 0 \\
\hline Polyscias fulva & 0 & 0 & 0 & 0 & 5 & 2 & 0 & 0 & 2 & 0 & 0 & 0 \\
\hline Pouteria adolfi-friederici & 2 & 2 & 0 & 0 & 0 & 0 & 0 & 0 & 0 & 0 & 0 & 0 \\
\hline Prunus africana & 3 & 4 & 1 & 2 & 1 & 1 & 5 & 2 & 0 & 0 & 0 & 3 \\
\hline Pterolobium stellatum & 0 & 0 & 0 & 1 & 0 & 1 & 0 & 0 & 0 & 0 & 0 & 0 \\
\hline Ricinus communis & 1 & 0 & 0 & 0 & 1 & 0 & 3 & 1 & 1 & 0 & 1 & 1 \\
\hline Salix subserrata & 0 & 0 & 0 & 0 & 0 & 0 & 0 & 0 & 1 & 0 & 0 & 0 \\
\hline Sapium ellipticum & 0 & 0 & 0 & 0 & 2 & 2 & 0 & 0 & 0 & 0 & 0 & 0 \\
\hline Sesbania sesban & 0 & 0 & 2 & 0 & 2 & 0 & 2 & 0 & 0 & 0 & 1 & 0 \\
\hline Schefflera abyssinica & 0 & 0 & 0 & 0 & 0 & 0 & 3 & 1 & 1 & 0 & 1 & 0 \\
\hline Spathodia nilotica & 0 & 0 & 0 & 0 & 0 & 0 & 1 & 1 & 0 & 0 & 0 & 0 \\
\hline Syzygium guineense ssp. guineense & 6 & 5 & 3 & 0 & 2 & 1 & 0 & 0 & 3 & 2 & 0 & 0 \\
\hline Vernonia amygdalina & 1 & 0 & 7 & 6 & 2 & 1 & 10 & 1 & 1 & 1 & 0 & 1 \\
\hline Vernonia auriculifera & 3 & 7 & 4 & 2 & 0 & 7 & 3 & 1 & 2 & 14 & 2 & 2 \\
\hline
\end{tabular}

$\dagger$ The numbers of tree species recorded in different villages were different: Doyyo 32; Kerebe 25; Maru 22; Hertanno 20; Kersa 26, and Kutture, 24.

I: Inside. B: On boundary. 